\title{
Вера Комарова, Светлана Королёва \\ СОЦИАЛЬНЫЙ КОНТЕКСТ СОЗДАНИЯ, ПЕРЕВОДА И ВОСПРИЯТИЯ УЧЕБНИКОВ ПО ЭКОНОМИКЕ 1990-х, 2000-х И 2010-х ГОДОВ
}

\author{
DOI: https://doi.org/10.9770/szv.2021.1(2)
}

Для цитирования: Комарова В., Королёва С. (2021) Социальный контекст создания, перевода и восприятия учебников по экономике 1990-х, 2000-х и 2010-х годов. Sociālo Zinātnu Vēstnesis / Вестник социальных наук, 32(1): 25-60. https://doi.org/10.9770/szv.2021.1(2)

For citation: Komarova V., Koroḷova S. (2021) Social context of creation, translation and perception of textbooks on economic of the 1990s, 2000s and 2010s. Sociālo Zinātņu Vèstnesis / Social Sciences Bulletin, 32(1): 25-60. https://doi.org/10.9770/szv.2021.1(2)

Цель и новизна данного исследования - системный анализ социального контекста создания, перевода и восприятия учебников по экономике 1990-х, 2000-х и 2010-х годов в латышскоязычном и русскоязычном пространствах. Объектом исследования является выборка $(n=61)$ учебников по экономике трёх поколений (1990-е, 2000-е и 2010-е годы) на латышском и русском языках, имеющихся в библиотеке Даугавпилсского Университета. Авторское исследование реализовано с помощью методов описательного анализа социального контекста и анализа случая (русских изданий классического учебника по экономике П. Самуэльсона), применённых в рамках лингвистического дискурсивного анализа с опорой на методологию культурного детерминизма М. Вебера. Результаты исследования показали, что деловая культура страны, экономический дискурс которой стал активно осваиваться в латышскоязычном и русскоязычном пространствах в 1990-е годы, т.е. культура США, значительно отличается от культуры Латвии и России. Кроме того, достаточно сильно различается между собой также деловая культура Латвии и России. Лингвистический дискурсивный анализ позволил вскрыть концептуальную проблему современной экономической науки в латышскоязычном и особенно русскоязычном пространствах, состоящую в том, что, несмотря на демонстрацию наличия некой общей экономической теории, в реальности даже такие универсальные экономические процессы, как производство и распределение, в учебниках по экономике часто представлены в разных системах координат - в зависимости от убеждений авторов учебников. Учитывая опыт социально-экономических метаморфоз как в течение последних 30 лет, так и в более ранние периоды, авторам представляется необходимым акцентировать особую значимость критического мышления при создании, переводе и восприятии современных учебников по экономике, поскольку нет никаких оснований полагать, что из сегодняшнего экономического дискурса латышскоязычного и русскоязычного пространств внезапно исчезла идеологическая начинка, характерная для многих предыдущих десятилетий (она несомненно изменилась, но вряд ли исчезла). Перед современными авторами, переводчиками и читателями учебников по экономике стоит нелёгкая задача самим критически оценивать любой учебник (особенно тот, создатели которого активно используют эмоциональную терминологию), не принимая за аксиому всё, что написано в учебниках по экономике.

Ключевые слова: текст, социальный контекст, экономический дискурс, учебники по экономике, лингвистический дискурсивный анализ, культурный детерминизм. 
1990. gados, 2000. gados un 2010. gados izdoto ekonomikas mācību grāmatu veidošanas, tulkošanas un uztveres sociālais konteksts

Šì pētījuma mērķis un novitāte ir 1990. gados, 2000. gados un 2010. gados izdoto ekonomikas mācību grāmatu veidošanas, tulkošanas un uztveres sociālā konteksta sistēmiska analīze latviešu un krievvalodīgajā telpā. Pētỉjuma objekts ir Daugavpils Universitātes bibliotēkā pieejamo trīs paaudžu (1990. gadu, 2000. gadu un 2010. gadu) ekonomikas mācību grāmatu izlase $(n=61)$. Pētījums tiek veikts, izmantojot aprakstošās analīzes metodi sociālā konteksta izpētei un gadījuma analīzes metodi P. Samuelsona klasiskās mācību grāmatas izdevumu krievu valodā izpētei. Šìs metodes tiek īstenotas lingvistiskās diskursanalīzes ietvaros, balstoties uz M. Vēbera kultūras determinisma metodolog̣iju. Pētījuma rezultāti parādīja, ka ASV lietiškā kultūra, kuras ekonomisko diskursu aktīvi apguva latviešu un krievvalodīgajā telpā 1990. gados, būtiski atšķiras no Latvijas un Krievijas kultūras. Turklāt arī Latvijas un Krievijas lietišķā kultūra ir diezgan atšķirīga. Lingvistiskā diskursanalīze palīdzēja atklāt mūsdienu ekonomikas zinātnes konceptuālo problēmu latviešu un, jo īpaši, krievvalodīgajā telpā - neskatoties uz to, ka ekonomikas mācību grāmatās tiek demonstrēta kādas vispārējas ekonomikas teorijas pastāvēšana, tomēr realitātē pat tādi universāli ekonomiskie procesi kā ražošana un sadale bieži tiek interpretēti dažādās koordinātu sistēmās - atkarībā no mācību grāmatu autoru uzskatiem. N̦emot vērā sociāli ekonomisko metamorfožu pieredzi gan pēdējo 30 gadu laikā, gan iepriekšējos periodos, autori uzsver kritiskās domāšanas īpašo nozīmi mūsdienu ekonomikas mācību grāmatu veidošanā, tulkošanā un uztverē, jo nav pamata uzskatìt, ka no mūsdienu latviešu un krievvalodīgās telpas ekonomiskā diskursa pēkšṇi pazuda daudzām iepriekšējām desmitgadēm raksturīgais ideologiskais piepildījums (tas noteikti mainījās, bet diez vai pazuda). Mūsdienu ekonomikas mācību grāmatu autoriem, tulkotājiem un lasītājiem ir grūts uzdevums pašiem kritiski novērtēt jebkuru mācību grāmatu (jo īpaši tādu, kuras veidotāji aktīvi lieto emocionālo terminologijiju), nepien,emot par aksiomu visu, kas tiek uzrakstìts ekonomikas mācību grāmatās.

Atslēgas vārdi: teksts, sociālais konteksts, ekonomiskais diskurss, ekonomikas mācību grāmatas, lingvistiskā diskursanalīze, kultūras determinisms.

Social context of creation, translation and perception of textbooks on economics of the 1990s, 2000s and 2010s

The purpose and novelty of this research is a systemic analysis of the social context of creation, translation and perception of textbooks on economics of the 1990s, 2000s and 2010s in the Latvian-language and Russian-language spaces. The object of the research is the sample ( $\mathrm{n}=61$ ) of Latvian and Russian textbooks on economics of three generations (1990s, 2000s and 2010s), available at the Daugavpils University library. The original authors' research is implemented using the descriptive analysis of the social context and the case study method (for analyzing Russian editions of the classic economic textbook by P. Samuelson). These methods are applied in the framework of the linguistic discourse analysis based on the methodology of M. Weber's cultural determinism. The results of the research showed that the business culture of the USA, which economic discourse began to be actively acclimated in the Latvian-speaking and Russian-speaking spaces in the 1990s, differs significantly from the culture of Latvia and Russia. Furthermore, the business culture of Latvia and Russia is also quite different. Linguistic discourse analysis made it possible to reveal the conceptual problem of modern economic science in the Latvian-speaking and especially Russian-speaking spaces. This problem is the following: despite the demonstration of the existence of some general economic theory, in reality even such universal economic processes as production and distribution are often explained in different systems of reference depending on the beliefs of the textbook author(s). Considering the experience of socio-economic metamorphoses both over the past 30 years and in earlier periods, the authors emphasize the special importance of critical thinking in the creation, trans- 
lation and perception of modern textbooks on economics. This is especially important, because there is no reasons to believe that in today's economic discourse of the Latvian-speaking and Russian-speaking spaces suddenly disappeared the ideological filling, which has been existing there during many previous decades (it surely changed, but unlikely disappeared). Modern authors, translators and readers of textbooks on economics face the difficult task to critically assess any textbook (especially one whose creators actively use emotional terminology) without taking for gospel everything that is written in textbooks on economics.

Key words: text, social context, economic discourse, textbooks on economics, linguistic discourse analysis, cultural determinism.

\section{Введение}

Социально-экономическое устройство - а вместе с ним и экономическая наука - Латвии и России на протяжении XIX-XXI веков переходили от дискурса капиталистической экономики конца XIX - начала XX века к дискурсу плановой социалистической экономики середины XX века, от неё - к дискурсу переходной экономики конца XX века и, наконец, - к дискурсу современной рыночной экономики начала XXI века (хотя в строго научном смысле современная экономика Латвии и России рыночной не является, но - так же, как в советский период «мы шли к коммунизму», теперь «мы идём к рынку»).

Параллельно этому процессу менялись и учебники по экономике, используемые для профессиональной подготовки экономистов, а также содержащаяся в них экономическая терминология. Сама экономика как наука (лат.: ekonomika, англ.: есоnomics) (Samuel'son 1964, 1994a, 1994b; Samuel'son, Nordhaus 2009; Makkonnell, Briu 1992, 2008; Stenleiks 1997; Bikse 2007, 2009), начиная с классической работы её родоначальника А. Смита (A. Smith) «Богатство народов» (coкращённое название) (лат.: “Tautu bagātība”, англ.: “Wealth of Nations”) (Smith 2007 [1776]) и вплоть до второй половины XX века называлась политической экономией (лат.: politekonomija или politiskā ekonomija, англ.: political economy) (Marx 1859; Zheleznov 1884; Sneiders 1925; Ostrovitianov i dr. 1954; Rumjancevs u.c. 1985; Nove 1986; Gregory 2004; Bikse 2009), ${ }^{1}$ а объект экономической науки в русскоязычных изданиях конца ХІХ века и в советских учебниках (а также в современных исследованиях о советской экономике) назывался народным хозяйством ${ }^{2}$ (лат.: tautas saimniecība или tautsaimniecība или saimniecība, ${ }^{3}$ англ.: national economy) (Zheleznov 1884; Gurko 1902; Liashchenko 1956; Sorokin 1961; Aizsilnieks 1968; Kirichenko 1974; Zalkind, Miroshnichenko 1980; Gulian 1982; Wheatcroft,

\footnotetext{
${ }^{1}$ Тем не менее, термин «политэкономия» ещё встречается, например, в 15-м издании классического переводного учебника по экономике П. Самуэльсона (Samuel'son, Nordhaus 1997: 6) и в русском переводе учебника П. Кругмана и М. Обстфельда «Международная экономика: теория и политика» (Krugman, Obstfel'd 1997); более того, французский экономист Т. Пикетти предлагает вернуться к этому названию экономической науки (Piketti 2015).

${ }^{2} \mathrm{~B}$ некоторых российских экономических изданиях начала XX века народное хозяйство даже отделялось от государственного (например, Gurko 1909; Vitte 1912).

${ }^{3}$ И политика, соответственно, была не экономической (Dovladbekova u.c. 2008), a хозяйственной (Stranga 2020) или народнохозяйственной (Zalkind, Miroshnichenko 1980).
} 
Davies 1985; Skujina 1995; Krumins 2017), и только в конце XX века в латышскоязычном и русскоязычном пространствах стал использоваться термин «экономика» (лат.: ekonomika) (Dunska 2001; Bikse 2009; Dubra 2009; Libs 2009; Medvedevs 2009; Krasnopjorovs 2013; Vilka 2016), что точнее соответствует английскому термину "economy"(Finkelstein 1992; Cleaver 2007).

Тем не менее, даже в названиях современных докторских диссертаций по экономике, защищённых в Латвии, ещё встречается термин “tautsaimniecỉba" - например, в докторской диссертации Г. Брастиня (G. Brastiňs) «Совершенствование управления кредитными рисками в народном хозяйстве Латвии» (лат.: "Kreditriska pārvaldības pilnveidošana Latvijas tautsaimniecībā", англ.: "Improvement of Creditrisk Management in the National Economy of Latvia") (Brastins 2015), а латвийское Министерство экономики (лат.: Ekonomikas ministrija, англ.: Ministry of Economics ${ }^{4}$ ) вплоть до 2016 года ежегодно публиковало «Отчёт о развитии народного хозяйства Латвии» (лат.: "Ziņojums par Latvijas tautsaimniecības attīstību”), и только начиная с 2018 года, Министерство экономики Латвии начало выпускать, соответственно, и «Отчёт о развитии экономики Латвии» (лат.: “Latvijas ekonomikas attīstības pārskats") (Latvijas Republikas Ekonomikas ministrija 2021). Кроме того, самих экономистов в Латвии в XXI веке ещё иногда называют «народнохозяйственниками» (лат.: tautsaimnieki) (Hofs, Marinska 2002), а у предприятий всё ещё имеются "tautsaimnieciskā funkcija un tautsaimnieciskais uzdevums" (Diderihs 2000 - перевод с немецкого).

Эти примеры свидетельствуют, кроме всего прочего, также и о том, что создание, перевод и восприятие латышскоязычных и русскоязычных текстов, репрезентирующих экономический дискурс, происходит в тесной связи с реальными социально-экономическими процессами, происходившими и происходящими в Латвии (и России), т.е. является контекстозависимым. Несмотря на то, что и Латвия, и Россия уже не одно десятилетие «идут по пути рыночной экономики», попрежнему актуальной является, например, проблема перевода и использования рыночной терминологии. Латвийский Центр государственного языка называет следующие основные вызовы в области перевода терминологии: использование синонимов для терминов, произвольное расширение, сужение или уточнение понятий (Valsts valodas centrs 2021), а также влияние других языков на национальную терминологию (Putele 2013).

Авторам не удалось найти ни в Латвии, ни в России системных исследований, посвящённых социальному контексту создания, перевода и восприятия латышскоязычных и русскоязычных учебников по экономике и его [контекста] роли в формировании экономического дискурса, поэтому целью (и новизной) данного исследования является анализ социального контекста создания, перевода и восприятия учебников по экономике 1990-х, 2000-х и 2010-х годов в латышскоязычном и русскоязычном пространствах. Объектом исследования является выборка $(n=61)$ учебников по экономике трёх поколений $(1990-\mathrm{e}, 2000$-е и 2010 -е

\footnotetext{
${ }^{4}$ Именно такой перевод - Ministry of Economics - дан на сайте Министерства экономики Латвии (https://www.em.gov.lv/en/about-us), что означает: Министерство экономической теории.
} 
годы) на латышском и русском языках, имеющихся в библиотеке Даугавпилсского Университета.

Авторское исследование реализовано с помощью следующих методов, используемых в рамках лингвистического дискурсивного анализа и с опорой на методологию культурного детерминизма М. Вебера (M. Weber):

1) метод описательного анализа (лат.: aprakstoša analizze, англ.: descriptive analysis) (Fairclough 1985; Kibrik 2003; Ukhvanova-Shmygova 2014) - для анализа социального контекста создания, перевода и восприятия латышскоязычных и русскоязычных учебников по экономике 1990-х, 2000-х и 2010-х годов;

2) анализ случая (лат.: gadijuma analize, англ.: case study) (Chakraborty et al. 2014; Danesi, Greco 2016; Тау 2019) - для анализа социального контекста русского перевода и восприятия классического рыночного учебника по экономике П. Самуэльсона (P. Samuelson).

В соответствии с методикой исследования строится и дальнейшая структура данной статьи, состоящая из двух основных частей - описательного анализа социального контекста создания, перевода и восприятия латышскоязычных и русскоязычных учебников по экономике 1990-х, 2000-х и 2010-х годов и анализа социального контекста русского перевода и восприятия классического учебника по экономике П. Самуэльсона, - предварённых описанием методологии исследования и завершающихся выводами по его результатам.

\section{Методология исследования}

В течение последних 30 лет учебники по экономике на постсоветском пространстве выполняли и продолжают выполнять, помимо прочих, «идеационную метафункцию» (Halliday, McIntosh 1985), с помощью которой конструируется связь латышскоязычных и русскоязычных читателей с опытом стран так называемой развитой рыночной экономики (прежде всего - США), не имевших в своей истории опыта советской экономики (Loginov 1989). ${ }^{5}$ Таким образом, учебники по экономике - в первую очередь, переводные, появившиеся в Латвии и России в период перехода от плановой экономики к рыночной - являются ярким примером того, что «между уровнем знаний читателей, на который рассчитывает автор оригинала, и предварительной информированностью целевых групп (пресуппозиции текста), на которую рассчитывает переводчик, может существовать заметная разница» (Dressler 1978: 63), являющаяся причиной проблем, в частности, с переводом и восприятием учебников по экономике, репрезентирующих совершенно новый для целевой аудитории экономический дискурс.

Методологической задачей данного исследования является не критическая, но «объясняющая» оценка учебников по экономике, что представляется наиболее выполнимым при использовании методологии лингвистического дискурсивного анализа (лат.: diskursanalize, англ.: discourse analysis) (Van Dijk 1976, 1985,

\footnotetext{
${ }^{5}$ В этой связи большой интерес представляет также изучение публикаций англоязычных западных авторов о советской экономике (например, Nove 1977, 1986), но это выходит за рамки объекта данного исследования.
} 
2006, 2008; Fairclough 1985; Benveniste 1985; Brown, Yule 1983; Jorgensen, Phillips 2002; Kibrik 2003, 2016; Widdowson 2004; Nord 2005; Hoey 2007; Cigankova 2009; Ticher i dr. 2009; Beilinson 2009; Chakraborty et al. 2014; Samigullina 2014; Bolsunovskaia i dr. 2015; Ptashkin 2016; Kopoloveca 2017; Cherniavskaia 2015, 2018; Romanovska 2021; Sarna 2021).

Авторы полагают, что для того, чтобы лучше ориентироваться в специфике лингвистического дискурсивного анализа, необходимо прежде всего хорошо понимать, что такое дискурс вообще в социальных науках и, в частности, в лингвистике. А. Кибрик в своей диссертации «Анализ дискурса в когнитивной перспективе» (2003) на соискание учёной степени доктора филологических наук определяет дискурс как «единство процесса языковой деятельности и её результата, то есть текста. Дискурс включает в себя текст как составную часть. Текст - статический объект, возникающий в ходе языковой деятельности. ... Дискурс, помимо самого текста, включает также разворачивающиеся во времени процессы его создания и понимания» (Kibrik 2003: 4). Здесь можно добавить краткое определение, данное В. Чернявской: «дискурс - это объединение текстов» (Cherniavskaia 2018: 32). Судя по дальнейшему ходу мысли В. Чернявской, надо полагать, что дискурс - это не простое суммирование текстов, а именно их синергетическое объединение. «Лингвистика дискурса устанавливает, как совокупность отдельных текстов создаёт общие смыслы» (Cherniavskaia 2018: 32). На следующем рисунке схематически представлено авторское понимание сущности дискурса в социальных науках и в лингвистике, основанное на анализе работ Т. Ван Дейка (T. Van Dijk) (1976, 1985, 2006, 2008), А. Кибрика (2003), В. Чернявской (2015, 2018) и Г. Миненкова (R. Miniankou) (2019), которая [схема], по мнению авторов, помогает также решить проблему отделения понятия «дискурс» от понятия «текст» (Kopoloveca 2017).

\section{Схема понимания сущности дискурса в социальных науках и в лингвистике}

Рисунок 1

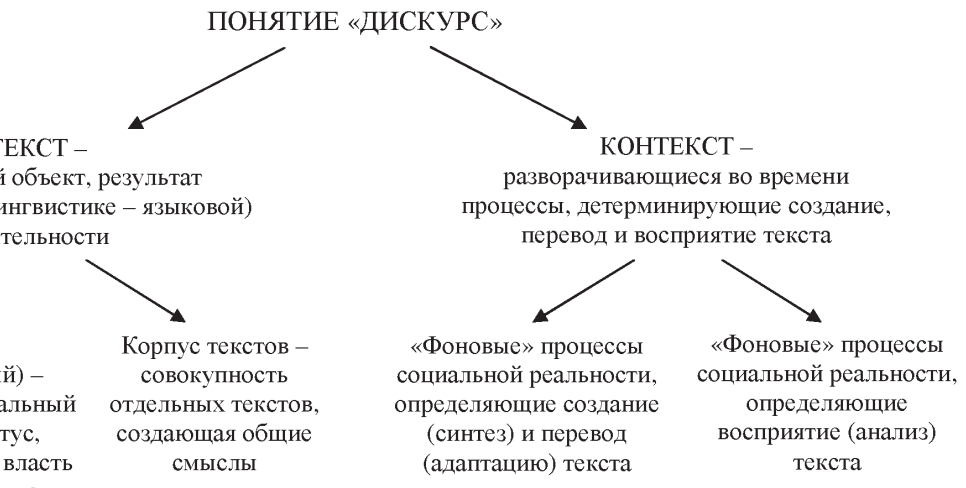

статический объект, результат социальной (в лингвистике - языковой деятельности

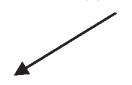

Языковой текст (письменный или устный) в лингвистике - или «социальный текст» (социальный статус, инвестиция, политическая власть и т.д.) - в социальных науках (адаптацию) текста -

Источник: создана авторами на основе работ Т. Ван Дейка (1976, 1985, 2006, 2008), А. Кибрика (2003), В. Чернявской $(2015,2018)$ и Г. Миненкова (2019). 
В представленной на Рисунке 1 схеме более чётко, нежели в текстовом изложении, воспринимается комплекс объекта и предмета авторского исследования это создание, перевод и восприятие учебников по экономике трёх поколений (1990-е, 2000-е и 2010-е годы) на латышском и русском языках и «фоновые» процессы социальной реальности, определяющие их создание, перевод и восприятие, т.е. лингвистическая сторона экономического дискурса (Beilinson 2009; Naidenova, Muradian 2017) 1990-х, 2000-х и 2010-х годов. В следующей таблице представлен «портрет» объекта авторского исследования.

Таблица 1

«Портрет» объекта авторского исследования -

учебников по экономике трёх поколений (1990-е, 2000-е и 2010-е годы) на латышском и русском языках, $n=61$

\begin{tabular}{lcccc}
\hline \multicolumn{1}{c}{ Показатели } & $\mathbf{1 9 9 0 - е ~ г о д ы ~}$ & $\mathbf{2 0 0 0 - е ~ г о д ы ~}$ & $\mathbf{2 0 1 0 - е ~ г о д ы ~}$ & Всего \\
\hline Количество учебников, шт. & 27 & 22 & 12 & 61 \\
\hline Из них: & & & & \\
- на латышском языке, шт. & 14 & 14 & 7 & 35 \\
- на русском языке, шт. & 13 & 8 & 5 & 26 \\
\hline - переводные, шт. & 11 & 7 & 7 & 25 \\
- непереводные, шт. & 16 & 15 & 5 & 36 \\
\hline - общеэкономические, шт. & 18 & 13 & 6 & 37 \\
- специализированные, шт. & 9 & 9 & 6 & 24 \\
\hline
\end{tabular}

Источник: составлено авторами.

Что касается вышеупомянутой проблемы отделения понятия «дискурс» от понятия «текст», то «обычно дискурс и текст противопоставлены друг другу с использованием ряда критериев такого противопоставления: функциональность / структурность, процесс / продукт, динамика / статика и актуальность / виртуальность» (Brown, Yule 1983: 24). Авторам представляется, что в соответствии со взглядами Т. Ван Дейка, выделявшего в дискурсивном анализе два аспекта - текстуальный и контекстуальный (Van Dijk 1985), можно определить дискурс в лингвистике очень коротко - как текст в контексте. Более того, по мнению авторов, такое определение дискурса может подойти для любой социальной (и даже естественной или технической) науки или направления искусства (или любой другой человеческой деятельности), если понимать концепт «текст» шире - как продукт любой человеческой деятельности (в лингвистике это - языковая деятельность (Kibrik 2003)). Тогда дискурсом в музыке будет музыкальное произведение («музыкальный текст») в контексте той социальной реальности, в котором оно создаётся, адаптируется и воспринимается, в живописи - картина («визуальный текст») в контексте социальной реальности её создания, реставрации и восприятия, в социологии - например, статус в обществе («социальный текст») в контексте социальной реальности его получения, трансформации и восприя- 
тия, ${ }^{6}$ в экономике - например, имущество («экономический текст») в контексте социальной реальности его создания, трансформации и восприятия, в автомобилестроении - автомобиль («технический текст») в контексте социальной реальности его создания, трансформации и использования, и т.д. Действительно, исследование в любой науке и в любой области человеческой деятельности будет гораздо более глубоким и системным, если изучать не только «текст» сам по себе, но и контекст его создания, адаптации и восприятия. Тогда, к примеру, роман «Война и мир» для лингвиста может выступать как в качестве текста, так и в качестве дискурса - в зависимости от того, изучается ли этот роман в социальноисторическом контексте его создания, перевода и восприятия или изучается только текстовой материал сам по себе (например, его структура, стиль, грамматика и т.д.). Концептуально то же самое происходит и в социологии - например, социальный статус предпринимателя может выступать как в качестве «социального текста», так и в качестве дискурса - в зависимости от того, изучается ли этот статус в социально-историческом контексте его получения, трансформации и восприятия обществом (например, от девиантного статуса «кулака» или «спекулянта» в советский период до статуса «движущей силы экономического развития» в период перехода к рыночной экономике) или изучаются только структурные характеристики социального статуса предпринимателя в современном обществе (например, так называемый социологический портрет современного предпринимателя - его доход, образование, национальность, семейное положение и т.д.).

Впервые такое широкое - общесоциальное - понимание концепта «текст» авторам встретилось в статье Г. Миненкова «Либеральное образование для глобального гражданства: на примере Европейского Гуманитарного Университета», опубликованной в 2019 году в этом же журнале, в которой он пишет об особенностях формирования учебной программы в рамках парадигмы либерального образования: «Ключевое значение при этом имеет формирование корпуса текстов (учитывая их общее количество, соотношение теоретических и художественных, вербальных и визуальных текстов). ... Важно подчеркнуть, что принципиальным критерием качества курса является авторская работа преподавателя с текстом (а не его «парафраз»), которая способна инициировать активный герменевтический подход к тексту со стороны студентов. Работу с ключевыми текстами в разных курсах необходимо при этом выстраивать как методически продуктивную при условии использования различных углов рассмотрения и способов чтения данных текстов» (Miniankou 2019: 18-19).

Необходимо отметить, что текст и контекст в рамках дискурса взаимно влияют друг на друга, т.е. текст создаётся, адаптируется и воспринимается в рамках контекста и под его влиянием, но в то же время созданный, адаптированный и воспринимаемый текст также влияет на окружающий его контекст, а если контекст создания текста и контекст его адаптации или восприятия представляют

\footnotetext{
${ }^{6}$ Таким образом, можно считать, что при проведении структурной и факторной операционализации в социологическом исследовании мы именно тем и занимаемся, что условно отделяем «социальный текст» (структуру) от контекста его функционирования (внешних и внутренних факторов).
} 
разные исторические периоды, то текст является своего рода мостиком между этими историческими периодами, позволяя прошедшему влиять на настоящее, т.е. осуществляя связь времён.

В рамках контекстуального подхода лингвистического дискурсивного анализа (Sarna 2021) принято считать, что текст как продукт языковой деятельности вплетён в некую «паутину значений» - сеть, сотканную и создателем, и адресатом, а также обществом и культурой (Girts 2004), в которых и стало возможной и востребованной конкретная деятельность по созданию, переводу и восприятию, в частности, учебников по экономике. В тексте и его интерпретациях обнаруживается сама история, поскольку любые высказывания, дискурсы и «дискурсивные комплексы» приобретают определённый смысл только в конкретной исторической ситуации (Sarna 2021), поэтому «паутину значений» можно понимать как культуру или систему смыслов, которые ориентируют людей по отношению друг к другу и окружающему миру (Girts 2004).

Контекстуальный уровень лингвистического дискурсивного анализа сопряжён с тем, что именно текст представляет, репрезентирует, воспроизводит, на что-то указывает и что-то называет. Это то, что принято называть «референтом» или «денотатом» высказывания и что открывает нам социальные отношения, в контексте которых происходит коммуникация субъектов, а также различные культурные коды, которые можно выделить в их речи (Sarna 2021). К числу представителей данного - контекстуального - направления относятся британские социологи M. Малкей (M. Malkey) и Дж. Гилберт (J. Gilbert), осуществляющие дискурсивный анализ высказываний учёных преимущественно в естественнонаучных кругах (Malkei 1983; Gilbert, Malkei 1987). Их работы посвящены относительно мало изученным сторонам научной деятельности и позволяют проанализировать социокультурные, институциональные, коммуникационные и личностные аспекты познания. В этом же русле работал и голландский исследователь Т. Ван Дейк, который создал ситуационную модель лингвистического дискурсивного анализа, рассматривая процессы коммуникационных взаимодействий не как жёстко алгоритмическую, но как гибкую стратегическую процедуру (Van Dijk 2008). Отталкиваясь от разработок в области грамматики текста, прагматики дискурса и когнитивного моделирования коммуникации, Т. Ван Дейк исследует специфику функционирования языка в средствах массовой информации с учётом таких социальных факторов, как мнения, установки говорящего и слушающего, их социальный статус, этническая принадлежность и так далее (Van Dijk 2008).

Авторы полагают, что наилучшим методологическим инструментом социологической теории, помогающим реализовать контекстуальный подход лингвистического дискурсивного анализа для изучения роли культуры как системы смыслов при создании, переводе и восприятии учебников по экономике, является культурный детерминизм М. Вебера. По М. Веберу, в основе социального развития (играя, как минимум, не меньшую, чем экономика, а скорее всего - большую роль) лежит относящаяся к сфере общественного сознания религия (Veber 1990). Религия для M. Вебера есть результат удвоения мира, и в этом смысле он не далёк от понимания марксистов, объясняющих религию как фантастическое отражение «в головах людей тех внешних сил, которые господствуют над ними в их по- 
вседневной жизни» (Engel's 1878 [1931]: 328). Но далее они расходятся; «если для марксистов религия как отражение социальной и природной действительности не играет первичной роли в социальном процессе, то для М. Вебера эта роль является определяющей, поскольку религия представляет собой систему ценностей и смыслов, мотивирующих и оправдывающих поведение (в том числе и экономическое - Прим. авт.) людей» (Trubitsyn 2009: 40).

\section{Описательный анализ социального контекста создания, перевода и восприятия латышскоязычных и русскоязычных учебников по экономике 1990-х, 2000-х и 2010-х годов}

Лингвистическое поле экономического дискурса отдельных этапов развития, через которые прошла Латвия и Россия в течение XX и XXI веков, содержало множество специфических экономических терминов - например, можно упомянуть такой типичный репрезентант дискурса плановой экономики, как «пятилетка» ${ }^{7}$ (лат.: piecgade) (Gladkov 1956; Kurskii 1974; Rumjancevs u.c. 1985), который на английский язык переводился только как 5-year plan (или five-year plan) (Nove 1977, 1986; Ellman 2014), кадры (лат.: kadri, ${ }^{8}$ англ.: cadrs) (Strazdina, Viksnins 1992) или «хозрасчёт» («хозяйственный расчёт») (лат.: saimnieciskais aprēķins, англ.: for-profit model или cost accounting или economic accountability) (Bunich 1970, 1989; Praude 1973; Strazdina, Viksnins 1992; Skujina 1995; Bakanov, Sheremet 1999; Litan, Herring 2001), а также широко известный репрезентант дискурса рыночной экономики - «невидимая рука» (лат.: neredzamā roka, англ.: invisible hand) рынка (Treisijs 1996; Paiders 2001; Ituell i dr. 2009), впервые употреблённый А. Смитом в своих классических работах ещё в XVIII веке и прочно вошедший практически во все современные учебники по экономике (Bikse 2007; Lobacheva 2010; Menk'iu 2010 и многие другие).

В начале 1990-х годов, когда постсоветская экономика переходила на рыночные рельсы (Gur'ianov, Nochevnik 1991), ${ }^{9}$ в учебники по экономике на латышском и русском языках вошло большое количество экономических терминов прямых заимствований с английского языка (например, «франчайзинг», «факторинг», «клиринг», «лизинг» и т.д.) (Garanca 2004; Spiridonova 2010). Многие

\footnotetext{
${ }^{7}$ Пятилетки и пятилетние планы существовали не только в СССР, но и в других странах - например, в Аргентине, Индии, Китае, Пакистане, а в Германии и Польше существовали так называемые «четырёхлетки» (англ.: four-year plan) (Ellman 2014).

${ }^{8}$ Термин "kadri” (параллельно с терминами “strādnieki”, “darbinieki” и “darbaspēks") всё ещё использовался в Латвии в 1996 и даже в 2004 году в учебниках по экономике для основной школы (Dike 1996; Jakovlevs 2004) и в российском учебнике по экономическому анализу (Bakanov, Sheremet 1999).

9 «Рыночные рельсы» - это широко распространённая метафора в русскоязычном экономическом дискурсе (Gur'ianov, Nochevnik 1991; Baltijas Starptautiska akademija u.c. 2017), происхождение которой [метафоры] авторам не удалось установить. В латышском языке, однако, она не прижилась, и здесь обычно используется выражение "pāreja uz tirgus ekonomiku” (Sinicins 2009).
} 
экономические термины появились в латышском и русском языках на волне «терминологического потопа» (Kondrat'eva 2001) 1990-х годов, а соответствующие им понятия либо отсутствовали вовсе, либо только формировались ${ }^{10}$ под влиянием текущих социально-экономических реалий (Makarova 2007; Streletskaia, Novakovskaia 2011; Gravem 2015). Очень ярким иллюстрирующим примером получившейся в результате этого лингвистической мозаики экономического дискурса является следующая цитата из российского непереводного учебника по теории экономического анализа, вышедшего в свет в 1999 году: «...английское издание «Бухгалтерский анализ» (1993, перевод), предназначенное в качестве учебника для банкиров, бизнесменов, менеджеров, бухгалтеров, статистиков, плановиков и аудиторов» (Bakanov, Sheremet 1999: 406). На этом примере хорошо видно, как в языке учебников по экономике 1990-х годов перемешались лексические репрезентанты плановой экономики («плановик») и рыночной экономики («бизнесмен», «менеджер»), встав буквально в один ряд.

Ещё одним примером такой лингвистической мозаики экономического дискурса может быть одновременное употребление терминологических словосочетаний «рыночная экономика» (репрезентант рыночной экономики) и «хозяйственная политика», «хозяйственные решения», «национально-хозяйственные особенности» (репрезентанты дискурса плановой экономики) в предисловии, написанном российскими учёными-экономистами, к переводу «Энциклопедии финансового менеджмента» американского экономиста Ю. Бригхэма (E. Brigham) (Brighem 1998).

Весь период, прошедший с начала перехода экономики Латвии и России к рынку, авторы условно разделила на три временных отрезка - 1990-е, 2000-е и 2010-е годы, хотя в реальности развитие экономического дискурса в течение всего этого 30-летнего периода происходило постепенно и то, что наиболее характерно, например, для периода 2000-х годов, начиналось уже в 1990-е годы и ранее. Тем не менее, в каждом из этих условных временных отрезков развития экономического дискурса в латышскоязычном и русскоязычном пространствах авторы попытались найти определённую доминанту, характеризующую социальный контекст создания, перевода и восприятия учебников по экономике, поскольку контекстуальный подход лингвистического дискурсивного анализа «рассматривает любое высказывание (текст) как продукт деятельности социальных агентов, всегда включённых в социальные взаимодействия и структуры, конкретную политическую и культурно-историческую ситуацию» (Sarna 2021).

Экспериментальный период создания, перевода и восприятия рыночных учебников по экономике (1990-е годы). В этот период в латышскоязычном и русскоязычном пространствах экономического дискурса вышло в свет большое количество учебников по экономике с указанием на то, что они являются экспериментальными изданиями (Raizberg 1994; Junior Achievement Latvijas nodala 1995), в основном созданными в рамках международных проектов (например, Krugman,

${ }^{10}$ Например, книги о рынке труда в России в начале 1990 -х годов уже публиковались (Nikiforova 1991), а самого рынка труда в стране ещё не было. 
Obstfel'd 1997), или имеют поисковый характер (лат.: meklëjuma raksturu) (Krievins 1996) и выпускаются с целью «обновления университетского экономического образования и приближения его к мировым стандартам» (Krugman, Obstfel'd 1997: предисловие к русскому изданию). Период 1990-х годов был очень противоречивым и интересным этапом в развитии экономического дискурса в латышскоязычном и русскоязычном пространствах. Один из ведущих советских экономистов С. Шаталин в книге «Рыночная экономика: выбор пути» (Gur’ianov, Nochevnik 1991) так охарактеризовал экономическую ситуацию, сложившуюся на тот момент в стране: «...хуже быть не может ... экономический кризис плюс полный дефицит на оптовом и потребительском рынках» (Gur'ianov, Nochevnik 1991: 5). На фоне такого социального контекста издававшиеся тогда учебники по экономике предварялись вступлениями примерно следующего содержания:

- «Осознание насущной необходимости в переходе страны к рыночной системе хозяйства привело к возникновению различных концепций рынка. Сама идея рынка перестала быть предметом обсуждения только специалистов, парламентариев, учёных. Она начала проникать в глубинные пласты общественного сознания, непосредственно затрагивая жизненные интересы каждого советского человека» (Gur'ianov, Nochevnik 1991: 3);

- «Бывают в истории такие случаи, когда буквально одно слово становится символом эпохи, вбирая в себя сложнейшие понятия в жизни не только одного какого-то народа, но и всего мира. ... Сейчас появилось русское слово, которое стремительно и прочно вошло во все словари мира: «перестройка». Оно утратило в данном случае своё первоначальное, узкопрактическое значение и стало общечеловеческим символом стремления всех народов мира так реорганизовать отношения между людьми, чтобы...» (Petrakov 1990: 11);

- «Включение экономики России в систему мирохозяйственных связей как рыночно-ориентированной и открытой экономики, подчас опережающее темпы её внутренней трансформации, породило огромное число проблем, требующих нестандартных и непривычных решений и более глубокого понимания, а значит и основательного изучения этих проблем. Наши старые представления в рамках нормативных курсов МЭО для этого оказались малопригодными» (Krugman, Obstfel'd 1997: предисловие к русскому изданию).

1990-е годы называют также периодом «рыночного романтизма» - представлений о том, что все стороны общественной жизни можно строить на рыночных принципах: личного материального интереса, частной собственности, конкуренции, с целью получения прибыли. Тем не менее, результаты социологических опросов населения г. Даугавпилса (Латвия), проводимых в 1990-е годы Лабораторией социологических исследований Даугавпилсского Педагогического Университета, показывали, что «идею рынка» (Gur'ianov, Nochevnik 1991) население принимало тогда далеко не единодушно (Mensikovs 1997). 
Рисунок 2

\section{Результаты социологического исследования - динамика распределения ответов жителей г. Даугавпилса (Латвия) на вопрос: \\ «Насколько Вы согласны с тем, что переход к рыночной экономике позволит выйти нашему обществу из глубокого кризиса и обеспечить нормальную жизнь людей?» в \%, 1990-1996 годы}

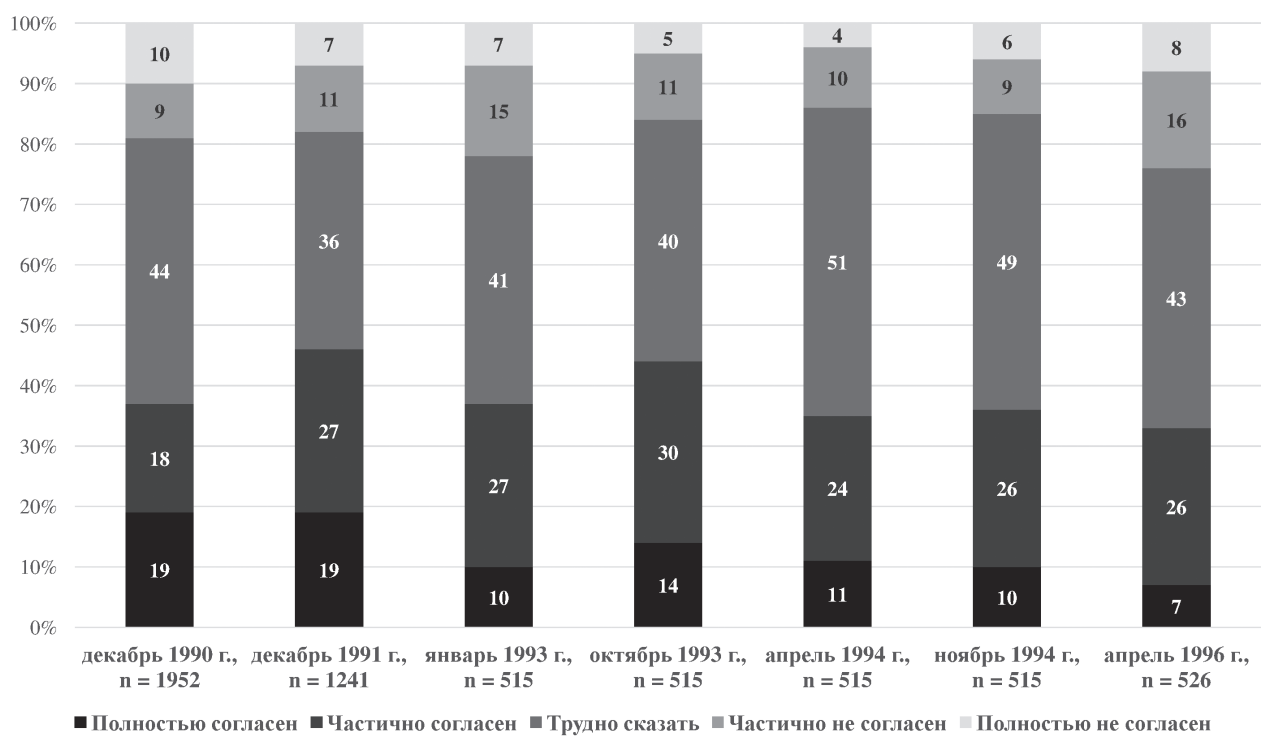

Источник: составлено авторами по Mensikovs 1997: 39.

В свою очередь, результаты авторского анализа содержания учебников по экономике, опубликованных в 1990-х годах, также свидетельствуют о том, что в экономическом дискурсе этого периода не было безоговорочного принятия рынка например, автор множества учебников по экономике в Латвии В. Биксе (V. Bikse) считала этот период переходом не к рынку, а к смешанной экономике (Bikse 1998: 13). В свою очередь, авторы пособия «для хозяйственных руководителей, работников плановых органов, преподавателей и студентов, научных работников» Л. Вид и Е. Иванов назвали свою книгу, вышедшую в свет в самом начале изучаемого периода - в 1990 году, - «Новая философия планирования» (Vid, Ivanov 1990), в которой они очень своеобразно интерпретируют характер «связей и соотношений между планом и рынком» (Vid, Ivanov 1990: 4), пытаясь представить их в единой системе координат: «Самое решительное расширение сферы действия товарно-денежных отношений и границ хозяйственной самостоятельности основного звена производства - предприятия - не только не ослабляет, но, наоборот, усиливает роль централизованного планирования. Именно такое диалектическое понимание изменений форм и методов планового ведения хозяйства определяет новые подходы в планировании, которые в полной мере предполагается осуществить в тринадцатой пятилетке« (Vid, Ivanov 1990: 4). 
В 1990-е годы появился термин «правовая экономика», прозвучавший из уст М. Горбачёва на Первом съезде народных депутатов СССР (Petrakov 1990), который [термин] в учебниках по экономике того времени интерпретировался следующим образом: «Установление чётких правовых норм, определяющих экономический суверенитет производителя и потребителя, является фундаментом демократизации экономической жизни, обеспечения права выбора хозяйственных партнёров, сфер приложения заработанных средств, ассортимента потребляемых продуктов и услуг. Всё это может быть достигнуто только путём развития социалистического рынка. Другого механизма демократизации хозяйственной жизни человечество не выработало. Мы должны освоить этот опыт в полном объёме и использовать его для повышения эффективности социалистической экономики» (Petrakov 1990: 7). А в издании с модным рыночным англоизированным названием - «Экономикс (именно так напрямую переносили в русский язык английское слово): теория и практика», содержащим «подробное и систематическое изложение основ предпринимательской деятельности» (Kanareikin 1993: обложка) и уже не претендующим на вклад в повышение эффективности социалистической экономики, а предназначенном для «предпринимателей и деловых людей» (Kanareikin 1993: обложка), живущих в стране, избравшей рыночный путь развития экономики, наряду с типичными репрезентантами рыночного дискурса - «факторы производства» и «маркетинг» - используется также и такая советско-рыночная конструкция, как «пропагандисты по сбыту товаров на предприятии» (Kanareikin 1993: 244).

В завершение описательного анализа периода «рыночного романтизма», отражённого в учебниках по экономике того времени, авторы приводят достаточно саркастическую цитату из статьи «Ламбада для дураков» (лат.: “Lambada mullkiem”) латвийского экономиста Ю. Балтгайлиса (J. Baltgailis), в название которой включён хоть и не экономический, но тоже характерный репрезентант того времени очень модный тогда латиноамериканский танец ламбада: «Вы помните, как весело начиналась «перестройка»? Решением какого-то летнего пленума ЦК КПСС было объявлено о необходимости создания рынка, потому что, к несчастью, система планирования тормозит. И партийная машина заработала, в срочном порядке пропагандируя рынок, - под возгласы особо приближённых академиков о том, что социализму как воздух нужны «рыночные отношения». Как заметил один из сатириков, «народ валом повалил на концерты экономистов», где им «вешали лапшу на уши», доказывая, что только благодаря «ускорению» мы со второй космической скоростью ворвёмся в мировые экономические просторы» (Baltgailis 1999: 34).

Таким образом, противоречивый социальный контекст создания, перевода и восприятия учебников по экономике в самом начале перехода Латвии и России к рынку детерминировал мозаичную специфику их текстов, включающих в себя языковые репрезентанты как плановой, так и рыночной экономики, а также оригинальные советско-рыночные конструкции.

Относительно зрелый постромантический период создания, перевода и восприятия учебников по экономике (2000-е годы). Следующему периоду, представляю- 
щему социальный контекст создания, перевода и восприятия учебников по экономике, предшествовало реальное экономическое событие, имевшее большие негативные последствия, в том числе и для Латвии (Baltgailis 1999), - мировой финансовый кризис 1997-1998 годов, который в наибольшей степени затронул страны Юго-Восточной Азии и Россию (Basovskii 2010) (так называемый дефолт 1998 года). По мнению авторов, это событие имело для экономического дискурса латышскоязычного и русскоязычного пространств своего рода эффект отрезвляющего холодного душа: «Реформаторы утверждали, что либерализация цен создаст рынок, который начнёт регулировать всю экономику, упорядочивая её развитие. Но инфляция уподобилась сказочному джину, которого выпустили из бутылки, и он доставил массу неприятностей и бед» (Borisov 2000: 196). По словам генерального директора одной из российских компаний В. Покорняка, «дефолт убил во мне некий рыночный романтизм. Сегодня я многое оцениваю по-другому» (Pokorniak 2002).

В этот период в предисловиях к издаваемым учебникам по экономике утверждалось, что «странам с бурно развивающейся экономикой - таким как Китай, Индия и Россия - трём гигантам, которые ещё сравнительно недавно ориентировались на централизованное планирование, - необходимо твёрдое понимание институтов рыночной экономики. Лишь в этом случае они могут достичь уровня жизни развитых стран мира» (Samuel'son, Nordhaus 2009: предисловие). В этот период также активно продолжается перевод новых изданий классических рыночных учебников по экономике (Makkonnell, Briu 2001, 2008; Briu, Makkonnell 2008; Samuel'son, Nordhaus 2009), представлявших, по заявлению их авторов, «чёткое, точное и, по возможности, интересное изложение основ современной экономической теории», включающие как «нетленные истины экономики», так и «политические проблемы нового столетия» (Samuel'son, Nordhaus 2009: предисловие).

В переводах учебников по экономике 2000-х годов отмечается, что «одним из основных препятствий к пониманию современной экономической теории является яркая палитра идей новых макроэкономических школ, соперничающих между собой. Преподаватели нередко удивляются: как этот предмет могут понять студенты, если сами специалисты по макроэкономике не в состоянии договориться друг с другом. Несмотря на то, что многие выражают обеспокоенность подобной ситуацией в современной макроэкономике, на наш взгляд, такое положение признак здоровья. Нам представляется, что живые дискуссии всё же лучше показного единодушия» (Samuel'son, Nordhaus 2009: предисловие).

Таким образом, в отличие от экспериментального периода создания, перевода и восприятия рыночных учебников по экономике 1990-х годов, смысл которых [учебников] преломлялся сквозь призму ещё совершенно советского сознания их создателей и переводчиков, доминантой периода 2000-х годов является относительная рыночная прозрелость экономического дискурса.

Критически-осмысливающий период создания, перевода и восприятия учебников по экономике (2010-е годы). Этому периоду, представляющему социальный контекст создания, перевода и восприятия наиболее современных учебников по 
экономике, - так же, как и предыдушему периоду, - предшествовало реальное экономическое событие, имевшее серьёзные негативные последствия для всего мира - мировой финансовый кризис 2008 года. По мнению авторов данного исследования, это событие имело для экономического дискурса латышскоязычного и русскоязычного пространств ещё более сильный эффект холодного душа, способствующий появлению в учебниках по экономике этого периода таких характерных лексем, как «в поисках другой экономики» (лат.: citas ekonomikas meklējumos), «закат «дутого» капитализма» (лат.: "pūstošā" kapitālisma noriets), «альтернативные пути развития» (лат.: alternatīvie attīstības celi), ««больная кровь» экономики» (лат.: ekonomikas "slimās asinis") (Plotkans 2010). Экономисты постсоветского пространства заговорили об особой значимости культурного контекста в экономическом дискурсе: «Несостоятельность свидетельствует о том, что культурные корни слабы или не подходят для доминирующих экономических отношений» (Plotkans 2010: 98).

Для периода 2010-х годов характерно довольно резкое сокращение выпуска учебников по экономике - их место всё больше занимают научно-исследовательские издания, анализирующие современную экономику и обсуждающие различные варианты выхода из кризиса (который, по мнению авторов, стал практически постоянной характеристикой всего изучаемого в данной статье периода) - например, латышский перевод книги знаменитого современного американского экономиста П. Кругмана (P. Krugman) «Возвращение депрессивной экономики и кризис 2008 года» (лат.: Depresīvās ekonomikas atgriešanās un 2008. gada krīze) (Krugmens 2010), латышский и русский переводы фундаментальной работы современного французского экономиста Т. Пикетти (Th. Piketty) «Капитал в XXI веке» (лат.: Kapitāls 21. gadsimtā) (Piketi 2015; Piketti 2015). Учебники по экономике этого периода становятся более аналитическими и менее азбучными, в них можно найти даже обоснованные призывы к возврату использования старой экономической терминологии, например: «Я предпочитаю словосочетание «политическая экономия», которое, возможно, звучит несколько старомодно, но обладает тем достоинством, что отражает единственную приемлемую особенность экономики в рамках общественных наук, которая заключается в её политическом, нормативном и нравственном измерении» (Piketti 2015: 587).

Более того, в течение последних нескольких лет в Рунете появились электронные копии знаменитого сталинского учебника политэкономии (Ostrovitianov i dr. 1954), в котором дана квинтэссенция советской экономической мысли 1930-х, 1940-х и начала 1950-х годов и в создании которого участвовали десятки советских экономистов. «Прошло немало времени, и вот поколение, не жившее при И. Сталине и едва помнящее СССР, стало всё чаще обращаться к опыту тех, кто построил первое в истории социалистическое общество. ... Читайте эту книгу. Учитесь по этому учебнику» (Informatsionnii portal storonnikov referenduma ob otvetstvennosti vlasti pered narodom 2021).

Таким образом, текущий период создания, перевода и восприятия учебников по экономике - это уже 2020-е годы - можно охарактеризовать как абсолютно плюралистический: сегодня в латышскоязычном и русскоязычном пространствах 
экономического дискурса вращаются учебники по экономике, репрезентирующие как классическую экономическую науку, так и дореволюционную, сталинскую, социалистическую, капиталистическую и т.д. В Латвии есть интересный пример перевода двух изданий учебника по экономике не с традиционного для латышскоязычных и русскоязычных экономистов английского языка, а с норвежского (Hofs, Marinska 2002; Hofs, Alsina 2011), в которых авторы обнаружили, к примеру, множество видов издержек производства, не встречающихся во всех других учебниках по экономике: накладные издержки (лат.: pieskaitāmās izmaksas), прогрессивно-переменные издержки (лат.: progresīi mainīgās izmaksas), пропорционально-переменные издержки (лат.: proporcionāli mainīgās izmaksas), регрессивно переменные издержки (лат.: regresīvi mainīgās izmaksas), скачкообразные постоянные издержки (лат.: lēcienveida pastāvīgās izmaksas), дифференциальные издержки (лат.: diferenciālās izmaksas) и т.д. Основной автор этого учебника - норвежский экономист К. Хофс (K. Hofs) - в течение нескольких лет преподавал в Рижском Техническом Университете на Факультете инженерной экономики и оставил после себя в экономическом дискурсе Латвии частичку норвежского экономического дискурса в виде двух учебных экономических текстов, репрезентирующих специфику именно норвежской экономической культуры и практики. Авторы полагают, что подобный опыт перевода учебных экономических текстов с совершенно разных языков (например, с китайского, арабского и всех возможных других языков) только обогатит экономический дискурс Латвии совершенно новой экономической культурой и практикой. При этом, правда, открытым остаётся вопрос о том, как - с использованием каких учебников - в настоящее время преподавать экономику в средних школах, колледжах и университетах.

Далее авторы считают целесообразным проиллюстрировать культурный аспект социального контекста экономического дискурса США (откуда в основном поступали учебники по экономике в латышскоязычное и русскоязычное пространства) в сравнении с культурным аспектом социального контекста экономического дискурса стран-реципиентов - Латвии и России. Поскольку культура наиболее инертный элемент человеческого общества и практически не поддаётся изменениям (Hofstede 2021a), то культурную составляющую, замеренную для многих стран мира в рамках знаменитого проекта измерений культуры (относящихся, главным образом, именно к деловой культуре) голландского учёного Г. Хофстеде (G. Hofstede) (Hofstede 1980, 2001), можно считать своего рода константой социального контекста создания, перевода и восприятия учебников по экономике в течение всего 30 -летнего периода, изучаемого в рамках данного исследования.

На следующем рисунке представлено графическое сравнение культуры трёх стран - Латвии, России и США - по шести измерениям Г. Хофстеде. 
Рисунок 3

Сравнение культуры Латвии, России и США по шести измерениям Г. Хофстеде

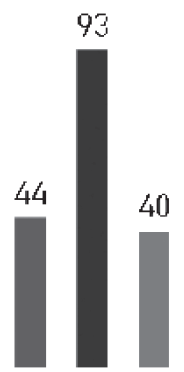

Power Distance

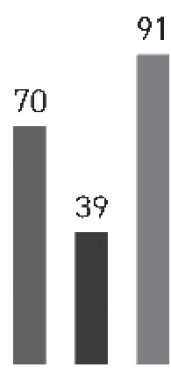

Individualism

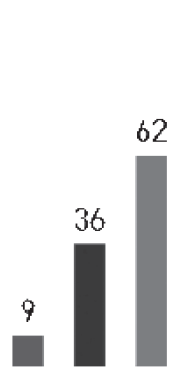

Masculinity

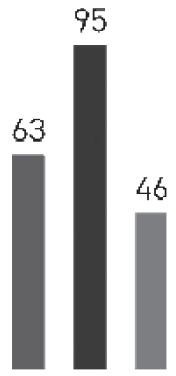

Uncertainty Avoidance
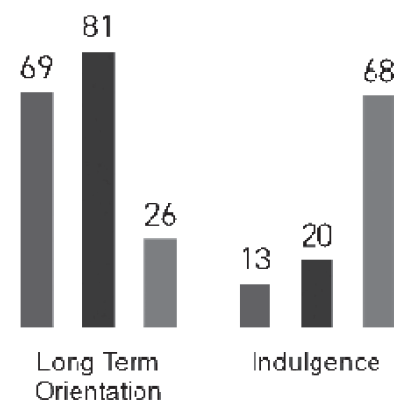

Indulgence

Страны на рисунке по порядку: Латвия, Россия, США.

Источник: составлено авторами по Hofstede 2021b.

Измерения культуры представляют собой доминирующие в обществе предпочтения одного положения дел перед другим, что отличает страны (а не отдельных лиц) друг от друга. Содержание измерений культуры, оцениваемых в баллах по шкале от 0 до 100, трактуется следующим образом (Hofstede 2021a):

1) Дистанция власти (англ.: Power Distance Index, PDI) - это измерение выражает степень, с которой рядовые члены общества принимают неравномерность распределения власти. Основным вопросом здесь является то, как общество воспринимает неравенство между людьми. Люди в обществах, демонстрирующих значительную степень дистанции власти, принимают иерархический порядок, в котором каждому есть место и который не нуждается в дополнительном обосновании. В обществах с малой дистанцией власти люди стремятся к равномерному распределению власти и требуют у властей обоснования неравенства.

2) Индивидуализм-коллективизм (англ.: Individualism versus Collectivism, IDV) первая крайняя точка этого измерения, называемая индивидуализмом, может быть определена как предпочтение слабо связанных социальных структур, в которых ожидается, что люди будут заботиться только о себе и своей нуклеарной семье. Его противоположность, коллективизм, представляет собой предпочтение тесно связанных социальных структур в обществе, в котором люди могут ожидать, что их родственники или члены определённой группы будут заботиться о них в обмен на полную лояльность. Позиция общества в этом измерении выражается в том, определяется ли самоощущение людей в терминах «я» или «мы».

3) Маскулинность-фемининность ${ }^{11}$ (англ.: Masculinity versus Femininity, MAS) «мужественная» сторона этого измерения представляет собой предпочтение

\footnotetext{
11 Это измерение совершенно не относится к социальной роли мужчин и женщин. Название «маскулинность-фемининность» произошло от того, что традиционно считается,
} 
обществом достижений, героизма, напористости и материального вознаграждения за успех. Такое общество в целом более ориентировано на соперничество. Его противоположность, «женственное» общество, отдаёт предпочтение сотрудничеству, скромности, заботе о слабых и качеству жизни. Такое общество в целом более ориентировано на согласие. В деловом контексте «мужественность против женственности» иногда также называют культурой «жёсткости против мягкости».

4) Избегание неопределённости (англ.: Uncertainty Avoidance Index, UAI) - это измерение культуры выражает степень дискомфорта, ощущаемого членами общества в ситуациях неопределённости и двусмысленности. Фундаментальный вопрос здесь заключается в том, как общество справляется с тем фактом, что будущее никогда не может быть познано: должны ли мы пытаться контролировать будущее или просто позволить ему случиться? Страны, демонстрирующие высокий уровень избегания неопределённости, обычно придерживаются жёстких поведенческих и ценностных кодексов и нетерпимы к неординарному поведению и идеям. В свою очередь, общества с низким уровнем избегания неопределённости более терпимы к неопределённости и неординарному положению дел, а потребности конкретной ситуации ставятся выше принципов.

5) Долговременная-кратковременная ориентированность (англ.: Long Term Orientation versus Short Term Normative Orientation, LTO) - каждое общество поддерживает определённые связи со своим прошлым, сталкиваясь с вызовами настоящего и будущего. Общества по-разному расставляют акценты по отношению к этим двум экзистенциональным дименсиям. Например, общества с низкими показателями по этому параметру, т.е. кратковременно-ориентированные, предпочитают придерживаться освящённых веками традиций и норм, с подозрением относясь к изменениям в обществе. В свою очередь, долговременно-ориентированные общества используют более прагматичный подход: они поощряют бережливость и прилагают усилия к улучшению современного образования, чтобы подготовиться к будущему. В академической среде это измерение культуры иногда также определяется как «гибкость-монументализм», при этом гибкость соответствует долговременной ориентированности, а монументализм - кратковременной.

6) Потворство желаниям-сдержанность (англ.: Indulgence versus Restraint, IVR) общество с высоким уровнем послаблений и потворства желаниям позволяет удовлетворять основные и естественные человеческие влечения, связанные с наслаждением жизнью и весельем. В свою очередь, общества с высоким уровнем сдержанности ограничивают удовлетворение потребностей и регулируют их с помощью строгих социальных норм.

Как видно из графического сравнения культур Латвии, России и США, представленном на Рисунке 3, культура страны, экономический дискурс которой стал

что стремление к достижениям и соперничество - это «мужской» тип поведения в обществе, а забота о ближнем и стремление к согласию - «женский». Во избежание путаницы авторы предлагают называть это измерение культуры как «соперничество-забота». 
активно осваиваться в латышскоязычном и русскоязычном пространствах в 1990-е годы, т.е. культура США, значительно отличается от культуры Латвии и России по всем шести измерениям, и, по выражению Г. Хофстеде, «мы не можем изменить национальную культуру, поэтому должны понимать и уважать её» (Hofstede 2021a). Достаточно сильно различается между собой также культура Латвии и России - прежде всего, по показателю дистанции власти (она значительно выше в России, чем в Латвии), индивидуализму (он значительно выше в Латвии, чем в России) и избеганию неопределённости (оно значительно выше в России, чем в Латвии) (см. Рисунок 3).

Но самым интересным по отношению к культурному аспекту социального контекста создания, перевода и восприятия учебников по экономике, по мнению авторов, является то, что и Латвия, и Россия (в отличие от США) имеют достаточно высокий балл по гибкости культуры (см. Рисунок 3), т.е. культура латышскоязычного и русскоязычного пространств, на которое в 1990-х годах пришёл рыночный экономический дискурс США, «носит прагматичный характер. В обществах с прагматической ориентацией люди верят, что истина во многом зависит от ситуации, контекста и времени. Они демонстрируют способность легко адаптировать традиции к изменившимся условиям» (Hofstede 2021b). Тем не менее, как отмечает в своих работах Г. Хофстеде и его последователи (Hofstede et al. 2010), такая адаптация «паутины значений» (Girts 2004) чужой культуры в значительной степени является формальной, поверхностной, показной. Например, в следующей цитате из перевода учебника по экономике двух американских экономистов - Р. Хейлбронера (R. Heilbroner) и Л. Туроу (L. Thurow) - очень сильно проявляется культурный контекст самого переводчика и его восприятие исходного текста, репрезентирующего сильно отличающийся от привычного для советского человека «социальный порядок» (Halliday 1987): «На деле в условиях конкуренции фирма, вынужденная следить за издержками и доходами, чтобы выжить, скорее будет скупердяйничать (вряд ли это был единственный вариант перевода, но переводчик выбрал именно это слово с явно негативным оттенком Прим. авт.) и искать одну только выгоду (здесь также проявляется скрытое неприятие советским сознанием товарно-денежных отношений, характерных для рынка, - Прим. авт.)» (Heilbroner, Turou 1994: 227).

Таким образом, из эмпирического анализа можно сделать следующие общие выводы, касающиеся культурного аспекта социального контекста создания, перевода и восприятия западных учебников по экономике в латышскоязычном и русскоязычном пространствах и практически совпадающие с выводами М. Вебера (Veber 1994):

- западная индустриальная цивилизация уникальна;

- капитализм, развитие которого детерминировано преимущественно социокультурными факторами, эндогенен Западу и является результатом исключительно западного пути развития;

- модернизация Востока, по меньшей мере, затруднена.

Однако следует иметь в виду, что капитализм как тип социального действия у М. Вебера не равен капитализму как способу производства, составляющему основу индустриального общества. Капитализм имел место почти во всех обществах, 
на базе всех религий, в том числе восточных, но развиться в сторону современного капитализма он смог только в Западной Европе и в США (перенесённый из Западной Европы). То есть «капиталистическая деятельность возможна в любом обществе, однако, согласно М. Веберу, чтобы стать основой общественного производства, ей нужна духовная легитимация, в то время как К. Маркс говорил об экономической необходимости» (Trubitsyn 2009: 41).

\section{Социальный контекст русского перевода и восприятия классического учебника по экономике П. Самуэльсона}

Классический учебник П. Самуэльсона представляет собой интереснейший случай для более глубокого анализа, поскольку в американском экономическом дискурсе он впервые появился в 1948 году, а в русскоязычном пространстве в 1964 году, почти за 30 лет до начала перехода экономики Латвии и России к рынку. Этот факт [появление русского перевода учебника П. Самуэльсона в 1964 году] был неожиданностью для авторов, поскольку сразу вызвал вопрос о необходимости и возможности перевода на русский язык «наиболее распространённого в настоящее время буржуазного учебника политической экономии в капиталистическом мире» - так назвал этот текст академик А. Арзуманян во Вступительной статье (занимавшей 12 страниц «разгромного» текста), предварявшей перевод пятого издания классического учебника по экономике, вышедшего в СССР в 1964 году с пометкой «для научных библиотек» и появившегося в библиотеке тогда ещё Даугавпилсского Государственного Педагогического Института (см. Рисунок 4).

Как позднее - уже в 1997 году - писали в Предисловии к переводу на русский язык 15-го издания учебника П. Самуэльсона (который, начиная с 12-го издания, стал выходить в соавторстве с В. Нордхаусом) профессора Л. Тарасевич и А. Леусский, «в то время эта, на первый взгляд, безобидная надпись [«для научных библиотек» - Прим. авт.] означала, что учебник доступен для ограниченного числа пользователей специальных фондов библиотек (Samuel'son, Nordhaus 1997: 43).

Во Вступительной статье к первому русскому переводу 5-го издания классического учебника П. Самуэльсона академик А. Арзуманян так объяснял необходимость перевода на русский язык этого «буржуазного» учебника в 1964 году: «В этом труде П. Самуэльсон выступает не как глава какой-либо одной школы или направления, а как систематизатор современных политико-экономических взглядов буржуазных идеологов. По его свидетельству, с положениями, включёнными в учебник, согласны $90 \%$ экономистов «западного мира». В этом и состоит «ценность» книги. ... Перевод книги, в которой достаточно полно представлен теоретический багаж нашего идеологического противника, даёт богатый конкретный материал для его критики с позиций творческого марксизма-ленинизма» (Samuel'son 1964: 5).

Таким образом, классический рыночный учебник по экономике появился в пространстве специального доступа экономического дискурса Латвии и России задолго до начала их перехода к рынку - в качестве «мальчика для битья» в узком 
академическом кругу. Как писали уже в 1997 году в Предисловии к переводу на русский язык 15-го издания учебника П. Самуэльсона профессора Л. Тарасевич и А. Леусский, «более полусотни страниц текста вступительной статьи и послесловия были посвящены принятой в то время уничижительной критике книги, которая была подана как образец буржуазной антинаучной экономической теории» (Samuel'son, Nordhaus 1997: 43).

Рисунок 4

Титульный лист первого перевода на русский язык классического учебника по экономике П. Самуэльсона, 5-е издание, 1964 год

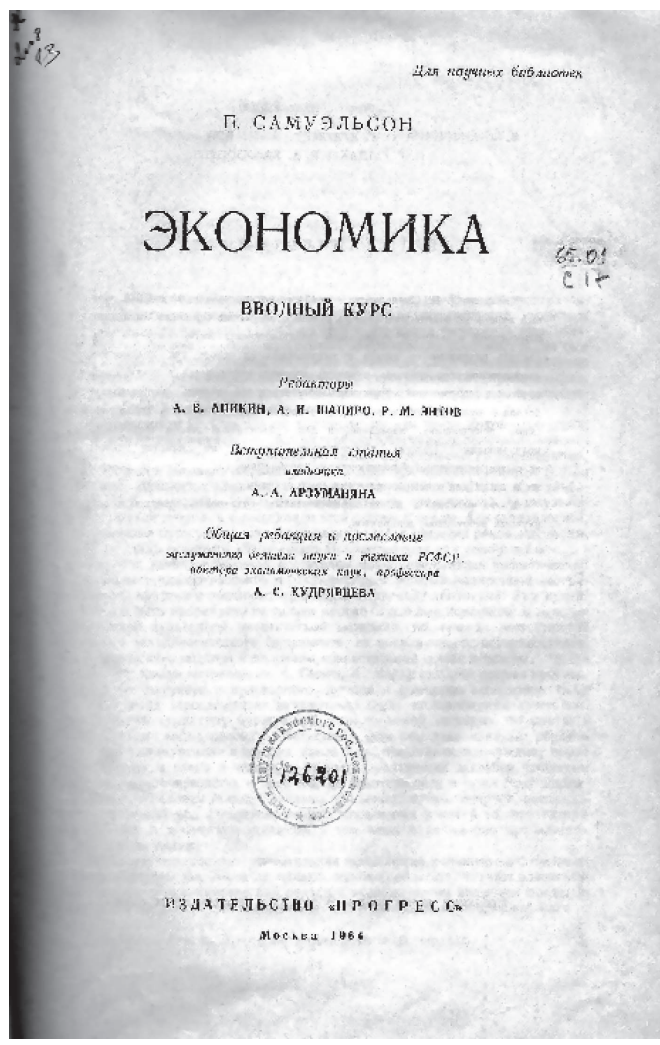

Источник: библиотека Даугавпилсского Университета.

Интересно, что сам П. Самуэльсон так оценивал факт перевода своего учебника на русский язык в 1964 году в своих «Размышлениях о сорок шестом дне рождения классического учебника по экономике» (1997): «Даже в бывшем Советском Союзе этот Троянский конь ${ }^{12}$ был переведён на русский язык, способствуя

\footnotetext{
${ }^{12}$ Фразеологизм, употребляемый в значении: тайный, коварный замысел, замаскированный под подарок.
} 
таким образом падению командной экономики, неэффективно управляемой тоталитарным бюрократическим аппаратом» (Samuel'son, Nordhaus 1997: 31). И здесь виден скрытый сюжет и замысел русского перевода этого учебника, не совпадающий с явным замыслом, представленным во Вступительной статье к русскому изданию П. Самуэльсона 1964 года. Здесь экономический дискурс наиболее тесно переплетается с политическим (см. также Naidenova, Muradian 2017), оставляя открытым вопрос о том, как воспринимали перевод учебника П. Самуэльсона на русский язык в 1964 году сами его заказчики и исполнители. Понимали ли они реальную «идеационную метафункцию» (Halliday, McIntosh 1985) этого учебника и содержащейся в нём рыночной терминологии в социальном контексте 1960-х годов?

В следующей таблице представлена информация об учебниках П. Самуэльсона, анализируемых в рамках данного исследования.

Таблица 2

Анализируемые учебники по экономике П. Самуэльсона

\begin{tabular}{|c|c|c|}
\hline Год издания & Библиографическая ссылка & Перевод \\
\hline 1964 & $\begin{array}{l}\text { Самуэльсон П. (1964) Экономика: } \\
\text { Вводный курс. 5-е изд. Пер. с англ. } \\
\text { Москва: Прогресс. }\end{array}$ & $\begin{array}{l}\text { Переводчики: В.Д. Антонова, } \\
\text { О.Г. Клесмет, А.К. Криворотченко, } \\
\text { П.Г. Олдака, Р.Х. Хафизова, } \\
\text { редакторы: А.В. Аникин, } \\
\text { А.И. Шапиро, Р.М. Энтов }\end{array}$ \\
\hline $1994 a$ & $\begin{array}{l}\text { Самуэльсон П. (1994а) Экономика. } \\
\text { Том 1. 5-е изд. Пер. с англ. Москва: } \\
\text { НПО «Алгон», ВНИИСИ, «Машино- } \\
\text { строение». }\end{array}$ & \multirow[t]{2}{*}{$\begin{array}{l}\text { Переводчики: В.Д. Антонова, } \\
\text { О.Г. Клесмет, А.К. Криворотченко, } \\
\text { П.Г. Олдака, Р.Х. Хафизова, } \\
\text { редактор: В. Арлазаров }\end{array}$} \\
\hline $1994 b$ & $\begin{array}{l}\text { Самуэльсон П. (1994б) Экономика. } \\
\text { Том 2. 5-е изд. Пер. с англ. Москва: } \\
\text { НПО «Алгон», ВНИИСИ, «Машино- } \\
\text { строение». }\end{array}$ & \\
\hline 1997 & $\begin{array}{l}\text { Самуэльсон П.А., Нордхаус В.Д. } \\
\text { (1997) Экономика: Учебное пособие. } \\
\text { 15-е изд. Пер. с англ. Москва: Бином- } \\
\text { КноРус. }\end{array}$ & $\begin{array}{l}\text { Перевод с английского под редак- } \\
\text { цией проф. Л.С. Тарасевича, проф. } \\
\text { А.И. Леусского }\end{array}$ \\
\hline 2009 & $\begin{array}{l}\text { Самуэльсон П.Э., Нордхаус В.Д. } \\
\text { (2009) Экономика: Классический } \\
\text { учебник. 18-е изд. Пер с англ. } \\
\text { Москва: ООО «И.Д. Вильямс». }\end{array}$ & $\begin{array}{l}\text { Перевод с английского } \\
\text { О.Л. Пелявского, под редакцией } \\
\text { д-ра экон. наук А.А. Старостиной } \\
\text { и канд. экон. наук В.А. Кравченко }\end{array}$ \\
\hline
\end{tabular}

Источник: составлено авторами.

Как видно из Таблицы 2, следующим изданием, уже входящим в объект данного исследования, стал 2-томный учебник по экономике П. Самуэльсона, вышедший в России уже после распада СССР - теперь уже абсолютно без комментариев (не было ни вступительной статьи, ни послесловия) (Samuel'son 1994a, 
1994b). Фактически это был тот же перевод 1964 года, вышедший тогда «с незначительными сокращениями» (Samuel'son 1964: резюме). Под сокращение тогда попали как минимум пять последних глав, которых авторы данного исследования не обнаружили в учебнике 1964 года, а именно: экономика расовых и половых отличий; качество жизни: нищета и неравенство, экология и рост, любовь и справедливость; полная занятость и цена стабильности в обществе со смешанной экономикой; ветер перемен: эволюция экономических доктрин; альтернативные экономические системы. Одна только цитата из этих глав делает понятной причину сокращений, сделанных в 1964 году даже в издании с ограничительной пометкой «для научных библиотек»: «Очевидно, что Советский Союз ещё не скоро (да и то вряд ли) превзойдёт наш действительный ВНП. Что же касается уровня благосостояния на душу населения, то это вообще вряд ли произойдёт» (Samuel'son 1994b: 413). Такие заявления никак не совмещались с советским политэкономическим дискурсом, представленным в Послесловии профессора А. Кудрявцева к первому русскому переводу классического учебника П. Самуэльсона: «...темпы роста производства в США, как известно, гораздо более низкие, чем в СССР и других социалистических странах» (Samuel'son 1964: 823), а также во Вступительной статье академика А. Арзуманяна, где сказано об «исторической неизбежности гибели капитализма, на месте которого американский трудовой народ рано или поздно, но неизбежно поднимет знамя подлинной свободы и братства - знамя социализма!» (Samuel'son 1964: 16).

Таким образом, реально первым переводом 1990-х годов классического учебника по экономике П. Самуэльсона можно считать вышедший в 1997 году русский перевод 15-го издания учебника (уже в соавторстве с В. Нордхаусом) и предварённый обращением П. Самуэльсона «К моему российскому читателю», в котором он писал: «Как это ни парадоксально, но хороший классический учебник по экономике будет более полезен для вашей страны, находящейся в стадии перехода от командно-бюрократического режима к системе смешанной рыночной экономики, нежели, скажем, американским или швейцарским студентам, изучающим политэкономию» (Samuel'son, Nordhaus 1997: 6). Этот учебник, в отличие от издания 1994 года, вышедшего без комментариев российских экономистов, уже содержал восторженно-хвалебное «Предисловие к русскому изданию», написанное российскими экономистами (Samuel'son, Nordhaus 1997). Сравнение комментариев советских / российских экономистов к русским изданиям разных лет классического учебника по экономике П. Самуэльсона, представленное в следующей таблице, заслуживает особого внимания с точки зрения лингвистического дискурсивного анализа. 
Таблица 3

Комментарии советских / российских экономистов к русским изданиям разных лет классического учебника по экономике П. Самуэльсона

\begin{tabular}{|c|c|}
\hline $\begin{array}{c}\text { Год издания } \\
\text { русского перевода } \\
\text { учебника }\end{array}$ & Комментарий советских / российских экономистов \\
\hline 1964 & $\begin{array}{l}\text { «Книга П. Самуэльсона - убедительное и предметное подтвержде- } \\
\text { ние положения Программы КПСС, что буржуазные учения и школы } \\
\text { не выдержали исторической проверки. Они не смогли и не могут } \\
\text { дать научного ответа на вопросы, выдвигаемые жизнью. Буржуазия } \\
\text { уже не в состоянии выдвинуть идеи, которые могли бы увлечь за со- } \\
\text { бою народные массы. Всё больше людей в капиталистических стра- } \\
\text { нах порывают с буржуазным мировоззрением. Буржуазная полити- } \\
\text { ческая идеология проповедовала догму о вечности и незыблемости } \\
\text { капитализма. Сколько бумаги было исписано, чтобы доказать, что } \\
\text { капитализм - это единственно возможный способ производства. } \\
\text { Сколько отравленных стрел было выпущено против марксизма, ко- } \\
\text { торый провозгласил, что капитализм - исторически преходящий } \\
\text { строй и ему на смену неизбежно придёт социализм» (Samuеl’son } \\
\text { 1964: 6). }\end{array}$ \\
\hline 1994a, 19946 & Комментарий российских экономистов отсутствует. \\
\hline 1997 & $\begin{array}{l}\text { «о сути эта книга есть синтез высокой науки и высокого искусства } \\
\text { изложения мысли. В силу этого обстоятельства мы сочли необхо- } \\
\text { димым издать книгу без каких-либо купюр и сокращений, чтобы } \\
\text { дать читателям возможность в полной мере оценить не только чёткую } \\
\text { логику и высочайший научный уровень, но и изящество стиля авто- } \\
\text { ров. Всякий учебник рассчитан на определённый круг читателей, и } \\
\text { было бы логично адресовать вводный учебник начинающим свой } \\
\text { путь в экономике. Однако мы убеждены, что пользу и удовольствие } \\
\text { от её прочтения получат не только непосвящённые в таинства эко- } \\
\text { номической науки, но и умудрённые читатели, ибо красота научной } \\
\text { мысли всегда будет привлекать подлинных ценителей» (Samuel’son, } \\
\text { Nordhaus } 1997: 44) \text {. }\end{array}$ \\
\hline 2009 & $\begin{array}{l}\text { «Экономика П. Самуэльсона и В. Нордхауса - классический учеб- } \\
\text { ник по экономической теории, который вот уже пятьдесят лет не } \\
\text { теряет своей актуальности. По этой книге изучают экономику ты- } \\
\text { сячи студентов в разных странах мира. Прочитав эту книгу, читатель } \\
\text { научится разбираться в сложном механизме современной эконо- } \\
\text { мики, познакомится с основами современной экономической тео- } \\
\text { рии и узнает о последних тенденциях в развитии экономической } \\
\text { мысли. Книга рассчитана на студентов и преподавателей экономи- } \\
\text { ческих факультетов, а также на любого вдумчивого читателя, инте-- } \\
\text { ресующегося глобальными тенденциями в мировой экономике и } \\
\text { политике» (Samuel'son, Nordhaus 2009: резюме). }\end{array}$ \\
\hline
\end{tabular}

Источник: составлено авторами по Samuel'son 1964, 1994a, 1994b; Samuel'son, Nordhaus 1997, 2009. 
По комментариям советских / российских экономистов к русским изданиям разных лет классического учебника по экономике П. Самуэльсона хорошо прослеживается процесс формирования экономического дискурса в русскоязычном пространстве середины XX - начала XXI века: от полного неприятия (и при этом перевода на русский язык) «буржуазной экономической теории капиталистических стран» (Samuel'son 1964: 5) и последовавшего за ним молчаливого шока от того, что именно этот «буржуазный» учебник становится одним из ведущих учебников по экономике в процессе профессиональной подготовки экономистов в русскоязычном пространстве 1990-х годов, через «рыночный романтизм» - к золотой середине: деловому подходу, лишённому как уничижительной критики, так и восторженных эмоций. Именно в этих комментариях и проявляется наиболее ярко специфика выразительных средств сообщения и коммуникации, носителями которых являлись советские / российские экономисты. В русских переводах учебника П. Самуэльсона, вышедших в 1990-х годах (а перевод 1994 года, как уже было отмечено выше, фактически является переводом 1964 года) встречаются такие непривычные для современного русскоязычного экономического дискурса термины, как «экономическая формация» (Samuel'son 1994b: 15), «деловые предприятия», «мельчайшие предприятия» (Samuel'son 1994b: 67), «трудовые отношения» (Samuel'son 1994b: 130), «экономика спекуляции» (Samuel'son 1994b: 81), «назначаемые рыночные цены» (Samuel'son 1994a: 61), «средства производства (земля и капитал)» (Samuel'son, Nordhaus 1997: 50), «производительные силы рынка» (Samuel'son, Nordhaus 1997: 51), которые уже практически не встречаются в русском переводе учебника П. Самуэльсона и В. Нордхауса 2009 года, а в переводе 1994 (фактически - 1964) года выдают плановый культурный контекст советских переводчиков, на который накладывалась совершенно новая для них рыночная терминология.

Реализация более глубокого, качественного подхода в рамках лингвистического дискурсивного анализа позволила также идентифицировать некоторое эмоциональное смягчение русскоязычного экономического дискурса, выражающееся в переходе от «враждующих школ в макроэкономике» (Samuel'son, Nordhaus 1997: 638) к «соперничающим макроэкономическим школам» (Samuel'son, Nordhaus 2009: 32) в переводах учебника П. Самуэльсона на русский язык.

Одновременно с формирования рыночного экономического дискурса в русскоязычном пространстве расширялась также и аудитория, и социальная сфера влияния учебника П. Самуэльсона: от узкого академического круга читателей первого русского перевода учебника П. Самуэльсона в 1964 году до студентов и преподавателей экономических факультетов, а также «широкого круга образованных людей» (Samuel'son, Nordhaus 1997: 44) и «любого вдумчивого читателя» (Samuel'son, Nordhaus 2009: резюме).

Как отмечает сам П. Самуэльсон в Предисловии к своим учебникам, «в социальных науках нужно особенно остерегаться «тирании слов». Мир весьма сложен и без того, чтобы в него привносились новая путаница и неясности, связанные с тем, что, во-первых, два различных слова по незнанию используются для обозна- 
чения одного и того же предмета, и, во-вторых, одно и то же слово применяется к двум совершенно различным явлениям. Джонс может назвать Робинсона лжецом за то, что, по мнению последнего, причина депрессий состоит в чрезмерных сбережениях, и утверждать, что действительной их причиной является недопотребление. Шварц может вступить в спор и заявить: «Вы оба неправы. В действительности корень зла надо искать в недостаточных инвестициях». Они могут спорить всю ночь, но, право же, если бы они прекратили спор и проанализировали свою терминологию, то без труда обнаружили бы, что их точки зрения полностью совпадают и что причиной спора была лишь словесная путаница» (Samuel'son 1964: 34; Samuel'son, 1994a: 11).

Кроме того, П. Самуэльсон справедливо - по мнению авторов - предостерегал от излишней эмоциональности в учебниках по экономике: «Слова могут оказаться предательскими ещё и потому, что они нам не безразличны. Так, человек, одобряющий государственную программу ускорения экономического роста, может назвать её «разумным планированием», тогда как лицо, питающее к этой программе антипатию, охарактеризует её как «тоталитарную бюрократическую регламентацию». Кто может возражать против первого и кто мог бы согласиться со вторым? Не нужно быть специалистом в области семантики - науки о смысловом значении языка, - чтобы понять, что научная дискуссия требует избегать, насколько это возможно, подобной эмоциональной терминологии» (Samuel'son 1964: 34; Samuel'son 1994a: 12).

Интересно, что и с творческим наследием М. Вебера - основоположника концепции культурного детерминизма общественного развития - в советском и постсоветском культурных пространствах происходила схожая с классическим учебником П. Самуэльсона метаморфоза, характерная для всех случаев политизации науки (Zarubina 1998; Trubitsyn 2009). Из оппозиционного мыслителя, запрешённого в годы идеологического господства марксизма-ленинизма, в пореформенной России М. Вебер перерос в свою противоположность, став идейным отцом российских теоретиков «самобытного пути» (Gaidenko, Davydova 1991; Zarubina 1998). Подвергая взгляды М. Вебера жёсткой критике, советское обществоведение указывало на его противоположность марксизму, говорило о несовместимости двух идей как идеализма и материализма в трактовке общественного. Сегодня существуют попытки буквально срастить творчество немецкого социолога с учением К. Маркса, нивелируя методологические отличия, являющиеся скорее взаимоисключающими, нежели взаимодополняющими, - независимо от социально-экономической и политической ситуации в той или иной стране (Trubitsyn 2009). «Срастить две позиции, представить одну как дополнение к другой, на наш взгляд, невозможно, поскольку М. Вебер создавал свою теорию именно как альтернативу марксизму. В своих трудах он буквально полемизирует с К. Марксом, противопоставляя его экономическому детерминизму свою социологию религии» (Trubitsyn 2009: 40). 


\section{Выводы}

Анализ социального контекста создания, перевода и восприятия латышскоязычных и русскоязычных учебников по экономике 1990-х, 2000-х и 2010-х годов, проведённый в рамках методологии лингвистического дискурсивного анализа и с опорой на методологию культурного детерминизма М. Вебера (эмпирически реализованную в исследованиях Г. Хофстеде), позволил вскрыть концептуальную проблему современной экономической науки в латышскоязычном и особенно русскоязычном пространствах, состоящую в том, что, несмотря на демонстрацию наличия некой общей экономической теории (например, “Ekonomikas teorijas pamatprincipi” (Bikse 2007), «Экономическая теория» (Borisov 2000; Lobacheva 2010)), в реальности даже такие универсальные экономические процессы, как производство и распределение, в учебниках по экономике часто представлены в разных системах координат - в зависимости от убеждений их авторов. ${ }^{13}$ Такой результат, по мнению авторов, свидетельствует о том, что лингвистический дискурсивный анализ способен «за языковыми асимметриями разглядеть социальные» (Prunch 2015).

Авторы полностью согласны с утверждением американских экономистов Р. Хейлбронера и Л. Туроу, согласующемся с концепцией культурного детерминизма М. Вебера о том, что «реальный вызов нашего времени - не в экономических проблемах, а в политических и моральных ценностях, которые всегда присутствуют в нашем экономическом поведении. Экономика - это язык, который мы используем, говоря о функционировании и возможностях нашей системы, но это вовсе не язык, на котором мы обсуждаем ценность самой системы или решаем, какие её элементы следует сохранить, а какие - изменить. Основой общества остаются политика и мораль - наша коллективная воля и наши личные системы ценностей» (Heilbroner, Turou 1994: 302).

Более того, учитывая опыт социально-экономических метаморфоз как в течение последних 30 лет, так и в более ранние периоды, авторам представляется необходимым акцентировать особую значимость критического мышления при создании, переводе и восприятии современных учебников по экономике, поскольку нет никаких оснований полагать (ибо культурный аспект социального контекста ни в Латвии, ни в России в 1990 году не изменился), что из сегодняшнего экономического дискурса латышскоязычного и русскоязычного пространств вдруг исчезла идеологическая начинка, характерная для многих предыдущих десятилетий (пусть теперь она уже другая по форме и содержанию, но от этого не меняется её социальная функция), с помощью которой незаметно формируется экономический дискурс наших дней, на который мы, возможно, в будущем будем смотреть с таким же удивлением, как сегодня смотрим на экономический дискурс 1960-х годов.

${ }^{13}$ Например, такой достаточно современный учебник как «Экономическая география и регионалистика» (Kuz’bozhev i dr. 2010) написан абсолютно марксистским языком с соответствующей терминологией. 
Перед современными авторами, переводчиками и читателями учебников по экономике стоит нелёгкая задача самим разобраться, например, в том, имеет ли капитализм «эксплуататорскую сущность» (Samuel'son 1964: 805, послесловие) и являются ли процент, рента и предпринимательский доход «эксплуататорскими доходами» (Samuel'son 1964: 823, послесловие), возможен ли в реальности «социалистический рынок» (Petrakov 1990: 7) и т.д., а также критически оценивать любой учебник - особенно тот, создатели которого активно используют эмоциональную терминологию, от которой предостерегал П. Самуэльсон, - не принимая всё, что написано в учебниках по экономике, за истину в последней инстанции.

\section{References}

Aizsilnieks A. (1968) Latvijas saimniecibas vesture 1914-1945. Riga: Daugava. (In Latvian) Bakanov M., Sheremet A. (1999) Teoriia ekonomicheskogo analiza: Uchebnik. Moskva: Finansy i statistika. (In Russian)

Baltgailis J. (1999) Parejas ekonomikas pakapes (Ka pasaules prakse transformejas Latvijas Republika). Daugavpils: DPU izdevnieciba "Saule". (In Latvian)

Baltijas Starptautiska akademija, Rigas Stradina universitate, Daugavpils Universitate, Uniwersytet Przyrodniczo Humanistyczny w Siedlcach. (2017) Transformacijas process tiesibas, regionalaja ekonomika un ekonomiskaja politika: ekonomiski politisko un tiesisko attiecibu aktualas problemas. VI Starptautiskas zinatniski praktiskas konferences rakstu krajums. Riga: BSA. Available: https://bsa.edu.lv/wp-content/docs/science/book/sbornik08122017.pdf (accessed on 28.05.2021). (In Latvian)

Basovskii L. (2010) Mirovaia ekonomika: Kurs lektsii. Moskva: Infra-M. (In Russian)

Beilinson L. (2009) Professional'nyi diskurs kak predmet lingvisticheskogo izucheniia. Vestnik Volgogradskogo Gosudarstvennogo Universiteta, Seriia 2: Iazykoznanie, № 1(9), s. 145-149. Available: https://cyberleninka.ru/article/n/professionalnyy-diskurs-kak-predmetlingvisticheskogo-izucheniya/viewer (accessed on 28.05.2021). (In Russian)

Benveniste E. (1985) On discourse. The Theoretical Essays: Film, Linguistics, Literature. Manchester: Manchester University Press.

Bikse V. (1998) Makroekonomikas pamati: teorija, problemas, politika. Riga: Latvijas Universitate. (In Latvian)

Bikse V. (2007) Ekonomikas teorijas pamatprincipi: Macibu lidzeklis. Riga: Izglitibas soli. (In Latvian)

Bikse V. (2009) Ekonomika un bankas: Macibu gramata. Riga: Latvijas Komercbanku asociacijas Konsultaciju un macibu centrs. (In Latvian)

Bolsunovskaia L., Zeremskaia Iu., Dubrovskaia N. (2015) Vidy diskursivnykh markerov v russkoiazychnykh i angloiazychnykh nauchnykh stat'iakh po geologii i neftegazovomu delu. Vestnik Tomskogo Gosudarstvennogo Pedagogicheskogo Universiteta (TSPU Bulletin), № 4(157), s. 117-123. Available: https://cyberleninka.ru/article/n/vidy-diskursivnyh-markerovv-russkoyazychnyh-i-angloyazychnyh-nauchnyh-statyah-po-geologii-i-neftegazovomu-delu/ viewer (accessed on 28.05.2021). (In Russian)

Borisov E. (2000) Ekonomicheskaia teoriia: Uchebnik. Moskva: Iurist. (In Russian)

Brastins G. (2015) Kreditriska parvaldibas pilnveidosana Latvijas tautsaimnieciba: Promocijas darbs. Riga: Latvijas Universitate. Available: https://dspace.lu.lv/dspace/bitstream/handle/7/ 
31323/298-51364-Braslins_Girts_gb10052.pdf? sequence $=1 \&$ isAllowed=y (accessed on 28.05.2021). (In Latvian)

Brighem Iu. (1998) Entsiklopediia finansovogo menedzhmenta: Sokr. per. s angl. Moskva: RAGS - "Ekonomika". (In Russian)

Briu S., Makkonnell K. (2008) Ekonomiks: Kratkii kurs. Per. s angl. Moskva: Infra-M. (In Russian)

Brown G., Yule G. (1983) Discourse Analysis. Cambridge: Cambridge University Press.

Bunich P. (1970) Problemy khozrascheta i finansov v usloviiakh reformy. Moskva. (In Russian)

Bunich P. (Red.) (1989) Khozraschet, samofinansirovanie, samoupravlenie. Moskva: Ekonomika. (In Russian)

Chakraborty G., Pagolu M., Garla S. (2014) Text Mining and Analysis: Practical Methods, Examples, and Case Studies Using SAS. SAS (Analytics Software \& Solutions) Institute. Available: http://support.sas.com/publishing/pubcat/chaps/65646.pdf (accessed on 28.05.2021). Cherniavskaia V. (2015) Lingvistika teksta. Lingvistika diskursa. Moskva: Nauka. (In Russian) Cherniavskaia V. (2018) Diskursivnyi analiz ikorpusnye metody: neobkhodimoe dokazatel'noe zveno? Ob'iasnitel'nye vozmozhnosti kachestvennogo I kolichestvennogo podkhodov. Voprosy kognitivnoi lingvistiki, № 2, s. 31-37. DOI: 10.20916/1812-3228-2018-2-31-37. (In Russian) Cigankova N. (2009) Linguistic Variation in English Computer Mediated Academic Discourse: Doctoral Dissertation. Riga: University of Latvia. Available: https://space.lu.lv/dspace/ bitstream/handle/7/4561/13740-Cigankova_promocijas_darbs.pdf? sequence=1\&isAllowed=y (accessed on 28.05.2021).

Cleaver T. (2007) Understanding the World Economy. Routledge.

Danesi M., Greco S. (Eds.) (2016) Case studies in Discourse Analysis. Licom Studies in Pragmatics. Available: https://www.researchgate.net/publication/301815499_Case_studies_in_ Discourse_Analysis_ed_M_Danesi_S_Greco (accessed on 28.05.2021).

Diderihs H. (2000) Uznemuma ekonomika. Tulk. no vacu val. Riga: Zinatne. (In Latvian)

Dike V. (1996) Ievads ekonomika. Sabiedribas zinibas pamatskolai: Skolotaju gramata. Riga: RaKa. (In Latvian)

Dovladbekova I., Eteris E., Zelmenis D. (2008) Eiropas Savienibas ekonomiska politika un Latvija. Riga: Rigas Stradina universitate. (In Latvian)

Dressler W. (Ed.) (1978) Current Trends in Text Linguistics. Berlin: de Gruyter.

Dubra E. (Red.) (2009) Latvijas ekonomikas konkuretspeja un investiciju nozime tas veicinasana: Monografija. Riga: LU Akademiskais apgads. (In Latvian)

Dunska M. (2001) Eiropas Savienibas ekonomikas pamati. Riga: Rasa ABC. (In Latvian)

Ellman M. (2014) Socialist Planning. $3^{\text {rd }}$ ed. Cambridge: Cambridge University Press.

Engel's F. (1878) [1931] Anti-Diuring. Marks K., Engel's F. Sochineniia, T. 14. Moskva, Leningrad: Sotcekgiz. (In Russian)

Fairclough N. (1985) Critical and descriptive goals in discourse analysis. Journal of Pragmatics, Vol. 9, Issue 6, pp. 739-763. DOI: https://doi.org/10.1016/0378-2166(85)90002-5

Finkelstein J. (1992) The American Economy: From the Great Crash to the Third Industrial Revolution. Illinois.

Gaidenko P., Davydova Iu. (1991) Istoriia i ratsional'nost': Sotsiologiia M. Vebera i veberovskii renessans. Moskva. (In Russian)

Garanca B. (2004) Vards - apakskomisijai. Ekonomikas terminologijas apakskomisija (ETAK). Terminologijas Jaunumi, 01.05. Available: https://termini.gov.lv/komisija/vards-apakskomisijaiekonomikas-terminologijas-apakskomisija-etak (accessed on 28.05.2021). (In Latvian) 
Gilbert Dzh., Malkei M. (1987) Otkryvaia iashchik Pandory: Sotsiologicheskii analiz vyskazivanii uchenykh. Per. s angl. Moskva: Progress. (In Russian)

Girts K. (2004) Interpretatsiia kul'tur. Moskva: Rossiiskaia politicheskaia entsiklopediia (ROSSPEN). (In Russian)

Gladkov I. (1956) Ot plana GOELRO k planu shestoi piatiletki. Moskva: Izdatel'stvo AN SSSR. (In Russian)

Gravem O. (2015) Terminologiia v protsesse formirovaniia: issledovanie perevoda s angliiskogo iazyka na russkii iazyk $v$ oblasti podvodnoi dobychi: Masteroppgave i russisk. Institutt for fremmedspråk, Universitet i Bergen. Veileder: Margje Post. Available: https://bora.uib.no/boraxmlui/bitstream/handle/1956/10310/133480088.pdf? sequence=1\&isAllowed=y (accessed on 28.05.2021). (In Russian)

Gregory P. (2004) The Political Economy of Stalinism: Evidence from the Soviet Secret Archives. Cambridge: Cambridge University Press.

Gulian P. (1982) Latviia v sisteme narodnogo khoziaistva SSSR. Riga: Zinatne. (In Russian) Gur'ianov S., Nochevnik M. (Otv. red.) (1991) Rynochnaia ekonomika: vybor puti. Moskva: Profizdat. (In Russian)

Gurko V. (1902) Ustoi narodnogo khoziaistva Rossii. Agrarno-ekonomicheskie etiudy. SPb.: Tipografiia A. Suvorina.

Gurko V. (1909) Nashe gosudarstvennoe i narodnoe khoziaistvo. Doklad, predstavlennyi V s"ezdu upolnomochennykh ob"edinennykh dvorianskikh obshchestv. SPb.: Leshtukovskaia Parovaia Skoropechatnia P. Iablonskogo. (In Russian)

Halliday M. (1987) Language as Social Semiotic. The Social Interpretation of Language and Meaning. London: Arnold.

Halliday M., McIntosh A. (Eds.) (1985) Language, Context, and Text. Aspects of Language in a Social-Semiotic Perspective. Victoria: Deakin University Press.

Heilbroner R., Turou L. (1994) Ekonomika dlia vsekh. Per. s angl. Novosibirsk: EKOR. (In Russian)

Hoey M. (2007) Text, Discourse and Corpora: Theory and Analysis. A\&C Black.

Hofs K., Alsina R. (2011) Biznesa ekonomika. 2. izd. Tulk. no norvegu val. Riga: Jana Rozes apgads. (In Latvian)

Hofs K., Marinska K. (2002) Biznesa ekonomika. 1. izd. Tulk. no norvegu val. Riga: Jana Rozes apgads. (In Latvian)

Hofstede G. (1980) Culture's Consequences: International Differences in Work Related Values. London, Beverly Hills: Sage Publications.

Hofstede G. (2001) Culture's Consequences: Comparing Values, Behaviours, Institutions and Organizations Across Countries. CA: Sage, Thousand Oaks.

Hofstede G., Hofstede G.J., Minkov M. (2010) Cultures and Organizations: Software of the Mind, $3^{\text {rd }}$ ed. McGraw Hill Professional.

Hofstede G. (2021a) Dimensions of National Culture. Hofstede Insights. Available: https://hi. hofstede-insights.com/national-culture (accessed on 28.05.2021).

Hofstede G. (2021b) Country comparison. Hofstede Insights. Available: https://www.hofstedeinsights.com/country-comparison/latvia,russia,the-usa/ (accessed on 28.05.2021).

Informatsionnii portal storonnikov referenduma ob otvetstvennosti vlasti pered narodom. (2021) Politicheskaia ekonomiia. Stalinskii uchebnik 1954. Available: https://zaotvet.info/ content/politicheskaja_jekonomija_stalinskij_uchebnik_1954 (accessed on 28.05.2021). (In Russian) 
Ituell Dzh., Milgeit M., N'iumen P. (Red.) (2009) “Nevidimaia ruka” rynka. Per. s angl. Moskva: GU-VShE. (In Russian)

Jakovlevs P. (2004) Ekonomika. Uzdevumi un lietiskas speles: Macibu lidzeklis. Riga: RaKa. (In Latvian)

Jorgensen M., Phillips L. (2002) Discourse Analysis as Theory and Method. London: SAGE Publications Ltd.

Junior Achievement Latvijas nodala. (1995) Lietiska ekonomika. Studiju celvedis: Macibu lidzeklis vidusskolam. Tulk. no anglu val. Lielvarde: Lielvards. (In Latvian)

Kanareikin S. (Otv. za vypusk) (1993) Ekonomiks: teoriia i praktika. T. 1. Spb.: AO Dorval', AO Riga. (In Russian)

Kibrik A. (2003) Analiz diskursa v kognitivnoi perspektive: Dissertatsiia na soiskanie uchenoi stepeni doktora filologicheskikh nauk. Moskva: Institut iazykoznaniia RAN. Available: https://iling-ran.ru/kibrik/DA_cognitive_perspective@Diss_2003.pdf (accessed on 28.05.2021). (In Russian)

Kibrik A. (2016) Teoriia kommunikatsii i lingvisticheskii analiz diskursa. Venediktova T., Gudkov D. (Red.) Osnovy teorii kommunikatsii. Moskva: Iurait, s. 141-151. (In Russian)

Kirichenko V. (1974) Dolgosrochnyi plan razvitiia narodnogo khoziaistva. Moskva: Ekonomika. (In Russian)

Kondrat'eva T. (2001) Leksiko-semanticheskie i derivatsionno-metaiazykovye osobennosti terminosfery "Ekonomika-Rynok-Pravo": Na materiale russkogo, angliiskogo i nemetskogo iazykov: Avtoreferat dissertatsii. Available: https://www.dissercat.com/content/leksikosemanticheskie-i-derivatsionno-metayazykovye-osobennosti-terminosfery-ekonomika-ryno (accessed on 28.05.2021). (In Russian)

Kopoloveca N. (2017) Lidera portreta radisanas modelis latviesu un cehu politiskaja diskursa: Promocijas darbs. Riga: Latvijas Universitate. Available: https://dspace.lu.lv/dspace/bitstream/ handle/7/37282/298-61873-Kopoloveca_Nadezda_nm11041.pdf? sequence=1\&isAllowed=y (accessed on 28.05.2021). (In Latvian)

Krasnopjorovs O. (2013) Latvijas ekonomikas izangsmi noteicosie faktori: Promocijas darbs. Riga: Latvijas Universitate. Available: https://mpra.ub.uni-muenchen.de/47550/1/MPRA_ paper_47550.pdf (accessed on 28.05.2021). (In Latvian)

Krievins V. (1996) Ekonomikas pamatkurss: Macibu lidzeklis. Riga: RaKa. (In Latvian)

Krugmens P. (2010) Depresivas ekonomikas atgriesanas un 2008. gada krize. Tulk. no anglu val. Riga: Jumava. (In Latvian)

Krugman P., Obstfel'd M. (1997) Mezhdunarodnaia ekonomika: teoriia i politika: Uchebnik. Per. s angl. Moskva: Ekonomicheskii fakul'tet MGU, IuNITI.(In Russian)

Krumins G. (Sast.) (2017) Latvijas tautsaimniecibas vesture. Riga: Jumava. (In Latvian)

Kurskii A. (1974) Nauchnye osnovy sovetskikh piatiletok. Moskva: Nauka. (In Russian)

Kuz’bozhev E., Koz'eva I., Svetovtseva M. (2010) Ekonomicheskaia geografiia i regionalistika: Uchebnoe posobie. Moskva: Iurait. (In Russian)

Latvijas Republikas Ekonomikas ministrija. (2021). Arhivs. Available: https://www.em.gov.lv/ lv/arhivs (accessed on 28.05.2021). (In Latvian)

Liashchenko P. (1956) Istoriia narodnogo khoziaistva SSSR. T. III: Sotsializm. Moskva: Gosudarstvennoe izdatel'stvo politicheskoi literaturi. (In Russian)

Libs S. (2009) Spele gala: sagrauta ekonomika. Kas mus sagaida nakotne? Riga: Zvaigzne ABC. (In Latvian) 
Litan R., Herring R. (Eds.) (2001) Brookings-Wharton Papers on Financial Services. Brookings Institution Press.

Lobacheva E. (Red.) (2010) Ekonomicheskaia teoriia: Uchebnik. Moskva: Iurait, Visshee obrazovanie. (In Russian)

Loginov V. (Otv. red.) (1989) Sovetskaia ekonomika: opyt, problemy, perspektivy: Sbornik statei. Moskva: AN SSSR. (In Russian)

Makarova A. (2007) Determinologizatsiia edinits iazyka ekonomiki i biznesa v sovremennom russkom iazyke: Avtoreferat dissertatsii. Moskva: Moskovskii Gosudartsvennyi Oblastnoi Universitet. Available: https://www.dissercat.com/content/determinologizatsiya-edinits-yazykaekonomiki-i-biznesa-v-sovremennom-russkom-yazyke (accessed on 28.05.2021). (In Russian) Makkonnell K., Briu S. (1992) Ekonomiks: printsipy, problemy i politika. Per. s angl. Moskva: Respublika. (In Russian)

Makkonnell K., Briu S. (2001) Ekonomiks: printsipy, problemy i politika: Uchebnik I. 13-e izd. Per. s angl. Moskva: Infra-M. (In Russian)

Makkonnell K., Briu S. (2008) Ekonomiks: printsipy, problemy i politika: Uchebnik II. 16-e izd. Per. s angl. Moskva: Infra-M. (In Russian)

Malkei M. (1983) Nanka i sotsiologiia znaniia. Moskva: Progress. (In Russian)

Marx K. (1859) A Contribution to the Critique of Political Economy. Progress Publishers.

Medvedevs R. (2009) Pasaules ekonomikas globalizacija un tas ietekme uz Latvijas ekonomiku. Riga: M. (In Latvian)

Menk'iu N. (2010) Printsipy ekonomiks. Per. s angl. SPb.: Piter. (In Russian)

Mensikovs V. (1997) Latgale cela uz konkuretspejigu tirgu. Daugavpils: DPU izdevnieciba "Saule". (In Latvian)

Miniankou R. (2019) Liberal'noe obrazovanie dlia global'nogo grazhdanstva: na primere Evropeiskogo Gumanitarnogo Universiteta. Socialo Zinatnu Vestnesis / Vestnik sotsial'nykh nauk, № 1(28), s. 7-23. DOI: https://doi.org/10.9770/szv.2019.1(1). (In Russian)

Naidenova N., Muradian A. (2017) Leksiko-semanticheskie parametry ekonomicheskogo diskursa: novostnye soobshcheniia na russkom, angliiskom i frantsuzskom iazykakh. Vestnik RUDN. Seriia: Teoriia iazyka. Semiotika. Semantika, № 8(1), s. 182-187. DOI: https://doi.org/ 10.22363/2313_2299_2017_8_1_182_187. (In Russian)

Nikiforova A. (1991) Rynok truda: zaniatost' i bezrabotitsa. Moskva: Mezhdunarodnye otnosheniia. (In Russian)

Nord C. (2005) Text Analysis in Translation: Theory, Methodology, and Didactic Application of a Model for Translation-Oriented Text Analysis. Rodopi.

Nove A. (1977) The Soviet Economic System. $1^{\text {st }}$ ed. Boston: Allen \& Unwin, Inc.

Nove A. (1986) The Soviet Economic System. $3^{\text {rd }}$ ed. Boston: Unwin Hyman, Inc.

Ostrovitianov K., Shepilov D., Leont'ev L., Laptev I., Kuz’minov I., Gatovskii L., Iudin P., Pashkov A., Pereslegin V., Starovskii V. (1954) Politicheskaia ekonomiia: Uchebnik. Moskva: Gosudarstvennoe izdatel'stvo politicheskoi literatury. (In Russian)

Paiders J. (2001) Peleka ekonomika. Riga: Zvaigzne ABC, Dienas Bizness. (In Latvian)

Petrakov N. (Red.) (1990) Ne smet' komandovat'! Moskva: Ekonomika. (In Russian)

Piketi T. (2015) Kapitals 21. gadsimta. Tulk. no francu val. Jelgava: Lauku biblioteku atbalsta biedriba. (In Latvian)

Piketti T. (2015) Kapital v XXI veke. Per. s frants. Moskva: Ad Marginem Press. (In Russian) Plotkans A. (2010) Cita ekonomika. Riga: Dienas gramata. (In Latvian) 
Pokorniak V. (2002) "Vo mne ubili rynochnyi romantizm". ksonline.ru. Available: https://ksonline.ru/nomer/ks/-/id/12392/ (accessed on 28.05.2021). (In Russian)

Praude V. (1973) Ispol'zovanie khozrascheta $v$ upravlenii roznichnoi torgovlei (na materialakh Latviiskoi SSR): Dissertatsiia na soiskanie uchenoi stepeni kandidata ekonomicheskikh nauk. Riga: Latviiskii ordena Trudovogo Krasnogo Znameni Gosudarstvennyi Universitet im. Petra Stuchki. Available: https://dspace.lu.lv/dspace/handle/7/539 (accessedon 28.95.2021). (In Russian)

Prunch E. (2015) Puti razvitiia zapadnogo perevodovedeniia: ot iazykovoi asimmetrii k politicheskoi. Per. s nem. Moskva: R. Valent. Available: https:/library.oapen.org/bitstream/id/ 18493da6-5f3d-4172-baa0-2ae8fca556d1/577790.pdf (accessed on 28.05.2021). (In Russian) Ptashkin A. (2016) Diskurs, diskursivnyi analiz i lingvisticheskie protsessory. Vestnik Tomskogo Gosudarstvennogo Pedagogicheskogo Universiteta (TSPU Bulletin), № 6(171), s. 66-70. Available: http://vestnik.tspu.edu.ru/files/vestnik/PDF/articles/ptashkin_a._s._66_70_ 6_171_2016.pdf (accessed on 28.05.2021). (In Russian)

Putele I. (Sast.) (2013) Aktualas tendences terminologijas teorija un prakse: Rakstu krajums. Riga: LU Latviesu valodas instituts. (In Latvian)

Raizberg B. (1994) Eksperimental'nye uchebnye programmy izucheniia ekonomiki v nachal'nykh, srednikh $i$ starshikh klassakh obshcheobrazovatel'nykh shkol, gimnazii, litseev. Moskva RASSIANA. (In Russian)

Romanovska A. (2021) Diskursa analize. Nacionala enciklopedija. Available: https://enciklopedija.lv/skirklis/8056-diskursa-anal\%C4\%ABze (accessed on 28.05.2021). (In Latvian)

Rumjancevs A., Kozlovs G., Volkovs M., Mileikovskis A., Atlasa M., Azarova M., Belousovs R., Mancevs V., Mohovs N., Mrackovska I., Skipetrovs A. (1985) Politekonomija. Riga: Zvaigzne. (In Latvian)

Samigullina A. (2014) Formirovanie sposobnosti k provedeniiu lingvisticheskogo analiza politicheskogo diskursakak professional'noi kompetentsii budushchikh perevodchikov. Sovremennye problemy nauki i obrazovaniia, № 6. Available: http://www.science-education.ru/ru/article/ view?id=16268 (accessed on 28.05.2021). (In Russian)

Samuel'son P. (1964) Ekonomika: V vodnyi kurs. Per. s angl. Moskva: Progress. (In Russian) Samuel'son P. (1994a) Ekonomika. T. 1. Per. s angl. Moskva: NPO “Algon”, VNIISI, “Mashinostroenie". (In Russian)

Samuel'son P. (1994b) Ekonomika. T. 2. Per. s angl. Moskva: NPO “Algon”, VNIISI, “Mashinostroenie". (In Russian)

Samuel'son P., Nordhaus V. (1997) Ekonomika: Uchebnoe posobie. Per. s angl. Moskva: Binom-KnoRus. (In Russian)

Samuel'son P., Nordhaus V. (2009) Ekonomika: Klassicheskii uchebnik. Per. s angl. Moskva: OOO “I.D. Vil'iams”. (In Russian)

Sarna A. (2021) Diskurs-analiz. Tsentr gumanitarnykh tekhnologii. Available: https:/gtmarket. ru/concepts/7232 (accessed on 28.05.2021). (In Russian)

Sinicins M. (2009) Ekonomika vidusskolai. Riga: RaKa. (In Latvian)

Skujina V. (Aut. kol. vad.) (1995) ELDO: Ekonomikas, lietvedibas un darba organizacijas termini. Riga: LZA Latviesu valodas instituts. (In Latvian)

Smith A. (2007) [1776] An Inquiry into the Nature and Causes of the Wealth of Nations. Amsterdam, Lausanne, Melbourne, Milan, New York, Sao Paulo: MetaLibri. Available: https://www.ibiblio.org/ml/libri/s/SmithA_WealthNations_p.pdf (accessed on 28.05.2021). 
Sneiders A. (1925) Politiska ekonomija. Riga: Nacionala Kultura. (In Latvian)

Sorokin G. (1961) Planirovanie narodnogo khoziaistva SSSR. Voprosy teorii i organizatsii. Moskva: Izdatel'stvo sotsial'no-ekonomicheskoi literatury. (In Russian)

Spiridonova E. (2010) Semanticheskie osobennosti ekonomicheskikh terminov (na materiale russkogo i angliiskogo iazykov). Aktual'nye problemy teoreticheskoi i prikladnoi lingvistiki: Sbornik nauchnykh trudov. Ul'ianovsk: UlGTU. Available: http://venec.ulstu.ru/lib/disk/2011/ Sosnina.pdf (accessed on 28.05.2021). (In Russian)

Stenleiks Dz. (1997) Ekonomikas pamati. Tulk. no anglu val. Riga: Zvaigzne ABC. (In Latvian) Stranga A. (2020) Karla Ulmana autoritara rezima saimnieciska politika 1934-1940. Riga: Latvijas Universitate. (In Latvian)

Strazdina V., Viksnins M. (Sast.) (1992) Tirdzniecibas ekonomikas, organizacijas un parvaldes terminu vardnica. Riga: Zinatne. (In Latvian)

Streletskaia I., Novakovskaia E. (2011) Nekotorye osobennosti perevoda ekonomicheskikh tekstov s angliiskogo iazyka na russkii. Mir sovremennoi nauki, № 6, s. 49-54. Available: https://publications.hse.ru/articles/73362621 (accessed on 28.05.2021). (In Russian)

Tay D. (2019) Time Series Analysis of Discourse Method and Case Studies. $1^{\text {st }}$ ed. Available: https://www.routledge.com/Time-Series-Analysis-of-Discourse-Method-and-Case-Studies/Tay/ p/book/9780367732677 (accessed on 28.05.2021).

Ticher S., Meier M., Vodak R., Veter E. (Red.) (2009) Metody analiza teksta i diskursa. Khar'kov: Gumanitarnyi tsentr. (In Russian)

Treisijs M. (1996) Lauksaimnieciba un partika tirgus ekonomika: Ievads teorija, prakse un politika. Tulk. no anglu val. Riga: Latvijas Valsts agraras ekonomikas instituts. (In Latvian) Trubitsyn D. (2009) Kul'turnyi determinizm v kontseptsii modernizatsii: filosofsko-metodologicheskii analiz. Voprosy filosofii, № 8, s. 39-55. Available: http://zabgu.ru/files/people/pdf_files/ temp/14/679/01_temp_file_.pdf (accessed on 28.05.2021). (In Russian)

Ukhvanova-Shmygova I. (2014) Kauzal'no-geneticheskii podkhod v kontekste lingvistiki diskursa. Minsk: BGU. (In Russian)

Veber M. (1990) Izbrannye proizvedeniia. Per. s nem. Moskva: Progress. (In Russian)

Veber M. (1994) Khoziaistvennaia etika mirovykh religii. Veber M. Izbrannoe. Obraz obshchestva. Per. s nem. Moskva: Progress, s. 43-77. (In Russian)

Valsts valodas centrs. (2021) Terminologijas konsekvence. Available: https://vvc.gov.lv/index. php? route=product/category \&path=177 (accessed on 28.05.2021). (In Latvian)

Van Dijk T. (1976) Narrative macro-structures. Logical and cognitive foundations. PTL: A Journal for Descriptive Poetics and Theory of Literature, No. 1, pp. 547-568. Available: http://www.discourses.org/OldArticles/Narrative\%20macrostructures.pdf (accessed on 28.05.2021).

Van Dijk T. (1985) Semantic Discourse Analysis. Handbook of Discourse Analysis, Vol. 2: Dimensions of Discourse. London: Academic Press. Available: https://citeseerx.ist.psu.edu/ viewdoc/download?doi=10.1.1.461.9250\&rep=rep1\&type=pdf (accessed on 28.05.2021).

Van Dijk T. (2006) Ideology and Discourse Analysis. Journal of Political Ideologies, Vol. 11, No. 2, pp. 115-140. DOI: https://doi.org/10.1080/13569310600687908

Van Dijk T. (2008) Discourse and Context. A Sociocognitive Approach. Cambridge: Cambridge University Press.

Vid L., Ivanov E. (1990) Novaia filosofiia planirovaniia. Moskva: Ekonomika. (In Russian) Vilka I. (2016) Sociala kapitala elementu izpete un novertejums ekonomikas attistibas konteksta Latvija: Promocijas darbs. Riga: Latvijas Universitate. Available: https://dspace.lu.lv/dspace/ 
bitstream/handle/7/34482/298-56298-Vilka_Ilze_if10032.pdf? sequence=1\&isAllowed =y (accessed on 28.05.2021). (In Latvian)

Vitte S. (1912) Konspekt lektsii o narodnom i gosudarstvennom khoziaistve, chitannykh Ego Imperatorskomu Visochestvu Velikomu Kniaziu Mikhailu Aleksandrovichu v 1900-1902 gg. SPb.: Tipografiia AO Brokgauz-Efron. (In Russian)

Zalkind A., Miroshnichenko B. (1980) Ocherki razvitiia narodnokhoziaistvennogo planirovaniia. Moskva: Ekonomika. (In Russian)

Zarubina N. (1998) Sotsiokul'turnye faktory khoziaistvennogo razvitiia: M. Veber i sovremennie teorii modernizatsii. SPb. (In Russian)

Zheleznov V. (1884) Ocherki politicheskoi ekonomii. SPb.: Tipografiia A. Suvorina. (In Russian) Wheatcroft S., Davies R. (Eds.) (1985) Materials for a Balance of the Soviet National Economy 1928-1930. Cambridge: Cambridge University Press.

Widdowson H. (2004) Text, Context, Pretext: Critical Issues in Discourse Analysis (Language in Society). London: Blackwell Publishing Limited. 